\title{
Advanced Catalytic Materials for Ethanol Oxidation in Direct Ethanol Fuel Cells
}

\author{
Yun Zheng ${ }^{1}$, Xiaojuan Wan ${ }^{1}$, Xin Cheng ${ }^{1}$, Kun Cheng ${ }^{2}$, Zhengfei Dai ${ }^{3, *} \mathbb{D}$ and Zhihong Liu ${ }^{1, *}$ \\ 1 Key Laboratory of Optoelectronic Chemical Materials and Devices, Ministry of Education, Jianghan \\ University, Wuhan 430056, Hubei, China; zhengyun@jhun.edu.cn (Y.Z.); wan@jhun.edu.cn (X.W.); \\ chengxin@jhun.edu.cn (X.C.) \\ 2 Institution for Interdisciplinary Research, Jianghan University, Wuhan 430056, Hubei, China; \\ chengkun027@outlook.com \\ 3 State Key Laboratory for Mechanical Behavior of Materials, Xi'an Jiaotong University, Xi'an 710049, \\ Shaanxi, China \\ * $\quad$ Correspondence: sensdai@mail.xjtu.edu.cn (Z.D.); liuzh@jhun.edu.cn (Z.L.)
}

Received: 31 December 2019; Accepted: 30 January 2020; Published: 1 February 2020

\begin{abstract}
Direct ethanol fuel cells (DEFCs) have emerged as promising and advanced power systems that can considerably reduce fossil fuel dependence, and thus have attracted worldwide attention. DEFCs have many apparent merits over the analogous devices fed with hydrogen or methanol. As the key constituents, the catalysts for both cathodes and anodes usually face some problems (such as high cost, low conversion efficiency, and inferior durability) that hinder the commercialization of DEFCs. This review mainly focuses on the most recent advances in nanostructured catalysts for anode materials in DEFCS. First, we summarize the effective strategies used to achieve highly active Ptand Pd-based catalysts for ethanol electro-oxidation, including composition control, microstructure design, and the optimization of support materials. Second, a few non-precious catalysts based on transition metals (such as $\mathrm{Fe}, \mathrm{Co}$, and $\mathrm{Ni}$ ) are introduced. Finally, we outline the concerns and future development of anode catalysts for DEFCs. This review provides a comprehensive understanding of anode catalysts for ethanol oxidation in DEFCs.
\end{abstract}

Keywords: anode catalysts; nanostructures; ethanol oxidation; direct ethanol fuel cells

\section{Introduction}

In recent decades, direct ethanol fuel cells (DEFCs) and direct methanol fuel cells (DMFCs) have received considerable attention as renewable energy sources $[1,2]$. They can play important roles in replacing traditional fossil fuels, and thus alleviating the energy crisis and reducing green-house gas emissions. When compared to DMFCs and hydrogen fuel cells, DEFCs show remarkable advantages, such as higher safety in the storage and transportation of ethanol, as well as lower costs for producing and handling ethanol fuels [3]. For example, hydrogen storage is still a major concern that hinders wide applications of hydrogen fuel cells [4]. Methanol is more toxic and tends to cross over membranes more easily than ethanol [5]. Moreover, ethanol demonstrates much higher volumetric energy density than hydrogen gas and methanol $(6.28 \mathrm{kWh} / \mathrm{L}$ for ethanol vs. $0.18 \mathrm{kWh} / \mathrm{L}$ for hydrogen stored at 70 bar and $25^{\circ} \mathrm{C}$ and $4.82 \mathrm{kWh} / \mathrm{L}$ for methanol [6]). In combination with other common merits of fuel cells, such as relatively low operating temperature and integrated system design, DEFCs show promising applications in portable power for electronics and power devices for vehicles. The main mechanism of DEFCs is to convert ethanol fuels into electricity by stripping the $\mathrm{C}-\mathrm{C}$ bonds in ethanol 
which simultaneously generates electrons, protons, and $\mathrm{CO}_{2}$ at the anode [7]. For example, the overall oxidation reaction of ethanol can be expressed as follows [8].

$$
\begin{aligned}
& \text { Ethanol oxidation reaction (EOR) at anode: } \mathrm{C}_{2} \mathrm{H}_{5} \mathrm{OH}+3 \mathrm{H}_{2} \mathrm{O} \rightarrow 2 \mathrm{CO}_{2}+12 \mathrm{H}^{+}+12 \mathrm{e}^{-} \\
& \text {Oxygen reduction reaction (ORR) at cathode: } 3 \mathrm{O}_{2}+12 \mathrm{H}^{+}+12 \mathrm{e}^{-} \rightarrow 6 \mathrm{H}_{2} \mathrm{O}
\end{aligned}
$$

In general, the trade-off between EOR and ORR determines the overall efficiency of DEFCs. However, due to the poor activity of catalysts, the EOR process cannot occur completely, and many byproducts such as acetaldehyde and acetic acid can be produced during EOR (Figure 1), which restricts the conversion of ethanol to $\mathrm{CO}_{2}$ [9]. Thus, incomplete ethanol oxidation and inferior conversion efficiency become the main obstacles for the commercial application of DEFCs. Furthermore, when it comes to the practical application of single DEFCs, the influence of operational parameters on the efficiency and stability of DEFCs have to be considered. For instance, Azam et al. investigated the effects of operational parameters (such as ethanol concentration, operating temperature, and mass flow rate) on a single-cell DEFC performance with a PtRu/Pt couple, achieving a specific power value of up to $8.70 \mathrm{~mW} \mathrm{~cm}^{-2}$ at $85^{\circ} \mathrm{C}$ at stable conditions [5]. Thus, it is critical to design highly active and stable catalysts and assemble them into DEFCs for further investigation [10].

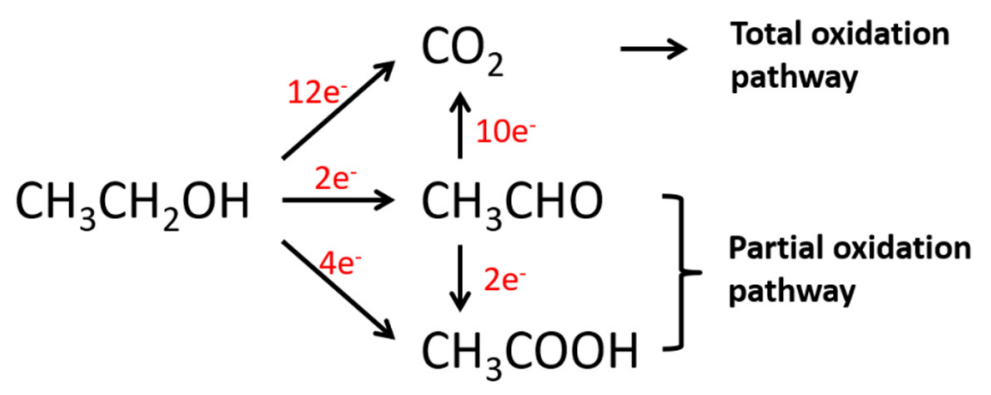

Figure 1. Schematic diagram of the parallel pathways during ethanol oxidation reaction (EOR) in acid media [11].

Currently, Pt-based catalysts have been developed as the most mature anode catalysts in DEFCs due to their superior activity towards ethanol electro-oxidation. However, the reaction intermediates (e.g., $\mathrm{CO}$ and $\mathrm{CH}_{\mathrm{x}}$ ) generated during the catalytic process can cause obvious surface poisoning of Pt-based catalysts, leading to the sluggish kinetics of ethanol reaction and thus weak service performance [12]. Therefore, the high cost of $\mathrm{Pt}$ and the relatively low durability are the main concerns for the wide applications of Pt electro-catalysts. Extensive efforts have been devoted to the development of binary Pt-based catalysts with reduced Pt loading or carefully controlled microstructures as well as the design of Pd-based and non-noble metal-based alternatives [13-15]. Bimetallic or trimetallic Pt-based alloys, such as PtSn [16], PtCu [17], PtCo [18], PtBi [19], and PtIrNi, [20] have emerged as promising electrocatalysts for EOR. Moreover, these Pt-based catalysts can mitigate the catalyst poisoning caused by the incomplete oxidation of $\mathrm{C}-\mathrm{C}$ groups in ethanol. The well-controlled microstructures of Pt- and Pd-based catalysts contribute to large specific areas and abundant active sites, which are beneficial for the catalytic process [21,22]. Novel synthetic routes have been developed to fabricate various catalysts with core-shell structures [23], nanowires [24,25], nanoplates [26], nanoparticles [27], and micropores [28]. Another important way to improve the catalytic performance of DEFCs is to strengthen the contact or interaction between catalysts and supports which can further enhance the electron and mass transfer [29]. Thus, substantial attention has been directed to the optimization of support materials for various ethanol electro-oxidation catalysts. Carbon black is among the most widely used supports for the catalysts due to its relatively high surface area and wide accessibility. Besides, graphene [30], carbon nanotubes [29,31], metal oxides [32], carbon fibers [33], metal hydroxides [34], and their hybrids [35,36] have been employed as alternative supports for ethanol electrocatalysts. 
Recently, many outstanding reviews have outlined both experimental and theoretical advances in anodic electrocatalysts for DEFCs $[1,8,14,37]$. However, to the best of our knowledge, few reviews have focused on Pt- and Pd-based anode catalysts as well as non-noble metal-based alternatives for DEFCs $[14,38]$. Moreover, a series of researches have reported the advanced catalytic performance for these promising materials in recent years. Thus, it becomes essential to contribute a timely review on this topic. In this review, we summarize the recent development of anode catalysts for ethanol oxidation in direct alcohol fuel cells. Both Pt- and Pd-based catalysts and alternative non-noble metal-based catalysts are involved with respect to their specific applications in ethanol oxidation. The strategies for further improving the catalytic activity and durability in EOR are summarized, which include the tailoring of chemical composition and microstructure as well as the optimization of support materials. Finally, the prospects and future development of anode catalysts for DEFCs are presented.

\section{Highly Active and Stable Pt- and Pd-Based Catalysts for EOR}

Pt- and Pd-based alloys are among the most popular catalysts for EOR which mainly show active performance in acidic and alkaline solutions, respectively. However, the pristine $\mathrm{Pt}$ and $\mathrm{Pd}$ often suffer from incomplete cleavage ability of $\mathrm{C}-\mathrm{C}$ bonds and unstable catalytic performance while subjected to long-term cyclic tests [9]. Together with the high cost of noble Pt and Pd, these concerns become the main obstacles for the commercial application of Pt and Pd. Therefore, substantial efforts have been directed to design highly active and stable catalysts for EOR, such as composition and morphology control, formation of composite catalysts, and optimization of support materials. This section will outline the recent advances in EOR electrocatalysts followed by implementation of these strategies.

\subsection{Nanostructure Engineering and Composition Control}

As the EOR process is sensitive to the microstructure of catalysts, the control over shape and size is important for enhancing the catalytic performance for EOR. Morphology control via nanostructure engineering has been widely employed to enlarge surface areas or to expose special facets, thus promoting reaction kinetics of $\mathrm{Pt}$ and Pd catalysts. To date, many novel methods have been developed to synthesize Pt and Pd catalysts with abundant nanostructures, including nanoparticles, nanowires, nanosheets, and nanopores [39]. However, stability remains a concern in these nanostructured Pt or Pd catalysts for EOR [40]. On account of this, foreign elements have been incorporated to form Ptand Pd-based alloys. This is an effective way to reduce the overall cost of catalysts and to improve their durability performance in DEFCs, which can be ascribed to the induced lattice mismatch and modification of electronic properties via the interaction between different components. To date, diverse Pt-based alloys have been synthesized by alloying with oxyphilic atoms, such as Sn [41], Bi [19], $\mathrm{Cu}$ [17], Zn [42], etc. In particular, bimetallic PtSn alloys exhibit advanced catalytic activity for EOR in both acidic and alkaline media due to the bifunctional mechanism, i.e., Sn can supply -OH species (by accelerating the dissociative adsorption of water ) at relatively low overpotentials that facilitate the oxidation of intermediates [41]. Moreover, the Sn-induced alternation of Pt electronic structure can weaken the bonding between $\mathrm{Pt}$ and poisonous $\mathrm{CO}$ species produced during the EOR process [43]. In general, it is a common practice to combine the beneficial effects of both morphology and composition control which can improve both catalytic activity and durability for Pt- and Pd-based catalysts [38].

Nanowire catalysts often possess low-coordinated sites, few grain boundaries, high aspect ratios and preferential crystal growth that are favorable for the EOR process [44]. Many efforts have been devoted to designing novel nanowire catalysts with superior catalytic performance. For example, ultrathin Pt nanowires outperform Pt nanoparticles in the EOR process due to the more abundant active sites exposed for ultrathin Pt nanowires. It is noteworthy that partial substitution of $\mathrm{Sn}$ for $\mathrm{Pt}$ can promote the formation of oxygenated species at a relatively low potential, which can alleviate the poisoning effect through the reaction between oxygen-containing groups and $\mathrm{CO}$ intermediates [41]. Thus, PtSn alloys often demonstrate accelerated ethanol electro-oxidation. Recently, Sn alloying and ultrathin structure design have been incorporated in Pt-based nanowires via a facile wet-chemical 
synthesis method [44]. Among these PtSn compounds with various compositions, the ultrathin $\mathrm{Pt}_{7} \mathrm{Sn}_{3}$ nanowires presented the highest activity towards EOR, such as the highest current density and lowest onset potential. The stability of $\mathrm{Pt}_{7} \mathrm{Sn}_{3}$ nanowires was also improved significantly. Moreover, the solution colloidal method has been used to synthesize sub-1 nm PtSn ultrathin sheets with the diameter in the range of $200 \mathrm{~nm}-1 \mu \mathrm{m}$ (Figure 2a,b). The achieved ultrathin PtSn nanosheets exhibited an advanced mass activity of $673.6 \mathrm{~mA} \mathrm{mg}_{\mathrm{Pt}}^{-1}$ in EOR, more than five times higher than commercial Pt black (Figure 2f) [41]. This result is among the highest activity towards EOR for PtSn-alloyed electrocatalysts [45]. The outstanding catalytic performance for EOR in both acidic and alkaline media should originate from the large exposed area of (111) facet in PtSn nanosheets, which can markedly improve the $\mathrm{C}-\mathrm{C}$ bond cleavage ability and remove the intermediate $\mathrm{CO}$ adsorbed on the catalyst surface. Flowerlike Pt-based nanocrystals have been synthesized through the hydro- or solvo-thermal method. Recently, Huang et al. incorporated porous structures into $\mathrm{Pt}_{54.5} \mathrm{Pd}_{45.5}$ nanoflowers via a facile aqueous solution synthesis [40]. The obtained products consisted of $\sim 5 \mathrm{~nm}$ subunits and many nanopores. The porous $\mathrm{Pt}_{54.5} \mathrm{Pd}_{45.5}$ nanoflowers showed much higher mass activity and stability towards ethanol oxidation compared to the commercial $\mathrm{Pt}$ black. This is mainly ascribed to the enhanced surface area to volume ratio and the nanopore-induced "nano-reaction pools" that can promote the interaction between fuel molecules and catalysts.
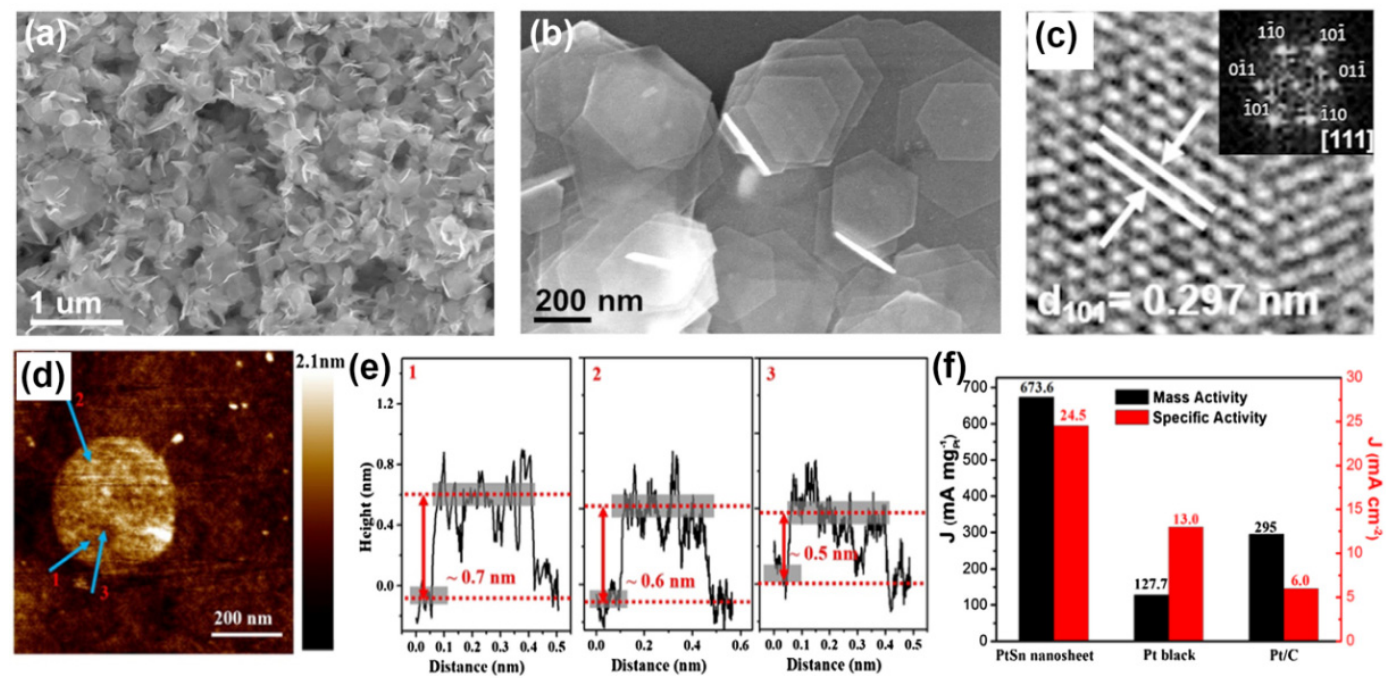

Figure 2. (a,b) Scanning electron microscopy (SEM) images and (c) high-resolution transmission electron microscopy (TEM) image of PtSn nanosheets, showing a lattice spacing of $0.297 \mathrm{~nm}$. The inset corresponds to the fast Fourier transform image of the same area. (d,e) Atomic force microscopy (AFM) image and the thickness of PtSn nanosheets. (f) The mass and specific activities (for EOR) of PtSn nanosheet, commercial Pt black and Pt/C. Reproduced with permission from [41]. Copyright 2019, Elsevier Ltd.

Pt-based catalysts mainly show superior EOR activity in an acidic environment, while Pd-based counterparts can fill the gap of oxidizing ethanol efficiently in alkaline media. Further, Pd is more earth-abundant and thus less expensive than Pt. Moreover, the oxyphilic nature of Pd facilitates the oxidative desorption process of intermediate byproducts, which can alleviate the catalyst poisoning effect to some extent. These unique features make Pd-based catalysts as important and promising alternatives in boosting EOR activity in alkaline electrolytes. Many metals (such as Ni [46-48], Sn [49,50], Ag [51,52], Au [53], Cu, Rh [49], and Ru [32]) or external additives (such as metal oxides [54,55] and hydroxides [56]) have been alloyed or mixed with Pd to form multicomponent systems with optimized catalytic performance and operational durability. Moreover, nanostructure engineering has been adopted to design Pd-based catalysts with enlarged surface areas and abundant active sites. In most cases, the collective effects of both metal alloying and microstructure design result in highly active 
Pd-based EOR catalysts with enhanced durability. Pd-Ni bimetallic nanoparticles were synthesized through a borohydride reduction method, which consists of large-area Ni nanoparticles modified by discrete Pd nanoparticles with an average diameter of $\sim 3 \mathrm{~nm}$ [48]. The Pd-Ni catalysts show more active EOR process compared to Pd catalyst alone. Also, the obtained Pd-Ni catalysts demonstrate a maximum EOR activity after cycling for 50 cycles with a potential limit of $+1.2 \mathrm{~V}$. This indicates that possible reorganization of PdNi catalyst surface occurs after certain cycles and thus results in the effective ethanol electrooxidation. The aforementioned Pd-based binary catalysts are mainly based on the mixtures of $\mathrm{Pd}$ metal and another metal component supported by carbon, which often show a more advanced EOR activity than a single $\mathrm{Pd} / \mathrm{C}$ electrode due to the synergistic effects from both components. However, these Pd-based mixtures often present relatively weak service performance, which can be ascribed to the possible rearrangement of catalyst surfaces or aggregation of catalysts under cycling test. On account of this, heterostructured nanocrystal catalysts have received great attention, which allows electronic interaction and interface engineering among the constituent elements. The heterostructured bimetallic nanocrystals usually demonstrate better catalytic activity and cycling performance than the single counterpart. Despite the wide-ranging methods employed in synthesizing heterostructured nanocrystals, it is still challenging to control the fine surface morphologies in order to achieve homogeneous and diversified microstructures for advanced catalytic performance. Recently, bimetallic Au@Pd core-shell nanostructures have been carefully designed which show an advanced catalytic performance towards EOR $[23,53,57]$. For instance, the seed-mediated epitaxial growth method has been employed to synthesize Au@Pd core-shell nanorods via controllable interface engineering (Figure 3) [23]. The surface morphology of Au@Pd nanorods can be facilely adjusted by the $\mathrm{pH}$ value of electrolytes and concentration of reducing agents or the Pd precursor. The (100)-faceted Au@Pd core-conformal shell nanorods exhibit nearly 4-fold higher mass activity towards EOR in alkaline environment as well as better cycling stability when compared to commercial Pd black catalysts. The highly stable Au@Pd nanorods mainly benefit from the rigid Pd shells supported by Au cores and the suppression of catalyst aggregation due to the low surface energy of core-shell structures. In addition, two-dimension (2D) configuration and metal alloying have been successfully implemented in achieving 2D PdAg nanodendrites with superior electrocatalytic activity and operation stability [51]. These two synergistic effects contribute to enlarged surface areas and abundant active sites as well as Ag-induced weakened binding between Pd and deleterious adsorbates.

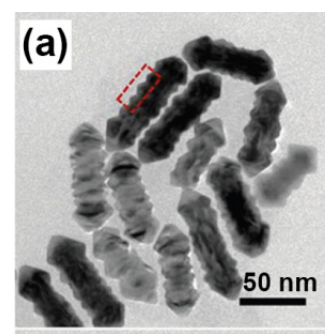

(c)

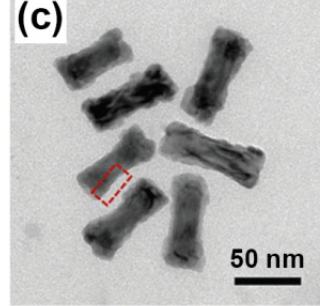

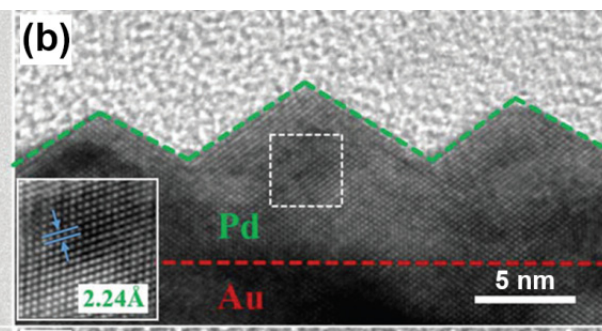

(d)

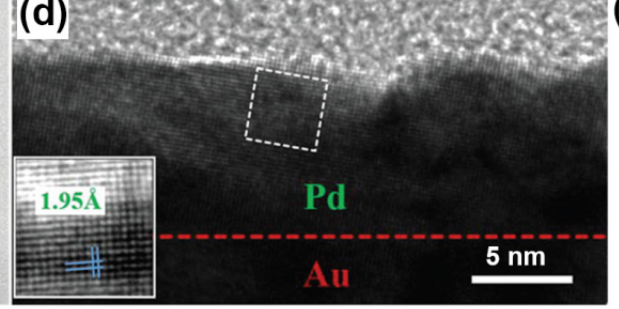

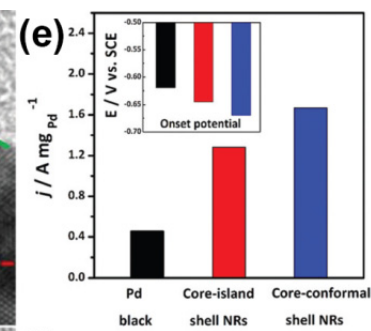

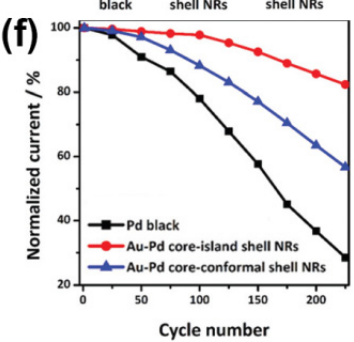

Figure 3. Transmission electron microscopy (TEM) and high-resolution TEM images of (a,b) Au@Pd core-island shell nanorods; and (c,d) Au@Pd core-conformal shell nanorods. (e) Mass activity for EOR on the two different nanorod catalysts in comparison with that of Pd black. The inset in (e) indicates the onset potential of these corresponding catalysts. (f) The EOR cycling stability for these catalysts with more than 200 cycles. Adapted with permission from [23]. Copyright 2018, Royal Society of Chemistry. 


\subsection{Configuration of Composite Catalysts}

In combination with optimized morphology and composition of Pt- and Pd-based catalysts as discussed above, suitable additives have been explored and introduced to further improve their catalytic activities for EOR. The typical co-catalysts include metal phosphides and oxides, such as $\mathrm{Ni}_{2} \mathrm{P}$ [58], $\mathrm{Fe}_{2} \mathrm{P}$ [59], $\mathrm{TiO}_{2}$ [32], $\mathrm{CeO}_{2}$ [60], $\mathrm{SnO}_{2}$ [61], $\mathrm{Sb}_{2} \mathrm{O}_{5}$ [35], etc, which exhibit excellent stability in acid or alkaline solutions. Further, these introduced additives can either modify the electronic structures of Pt- and Pd-catalysts or expedite the oxidation of intermediate species. In general, it is difficult to maximize the activity of Pt-based catalysts by simple phosphorus doping due to its limited doping concentration [62]. On account of this, various transition metal phosphides have been developed as catalysts promoters that can help suppress the poisoning effect in the oxidation process of

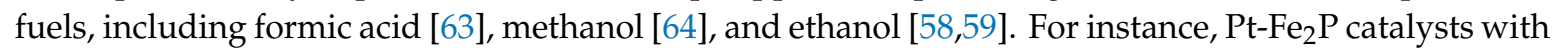
petal-like structures and anchored Pt nanoparticles $(\sim 2 \mathrm{~nm})$ were synthesized by microwave-assisted alcohol reduction method [59]. The hybrid catalysts showed excellent catalytic activity, $\sim 3$-fold that of the control $\mathrm{Pt} / \mathrm{C}$ catalyst, and highly improved stability over the $\mathrm{Pt} / \mathrm{C}$ catalyst. This could be ascribed to the strong coupling effect at the interface of $\mathrm{Pt}$ and $\mathrm{Fe}_{2} \mathrm{P}$, including strong electronic interaction and facile reactant transportation. Most of these studies utilized a two-step method to incorporate metal phosphides into Pt- or Pd-based catalysts. This is tedious and time-consuming. In addition, a recent study by Liu et al. reported a facile one-step hydrothermal approach to achieve $\mathrm{Pt}-\mathrm{Ni}_{2} \mathrm{P}$ composite catalysts supported on graphene [58]. $\mathrm{Pt}$ and $\mathrm{Ni}_{2} \mathrm{P}$ nanoparticles were anchored on the graphene surface with an average size of $\sim 2 \mathrm{~nm}$. The composite catalysts exhibited the best catalytic performance for EOR at an optimal $\mathrm{Ni}_{2} \mathrm{P}$ concentration of $20 \mathrm{wt} \%$, which can be attributed to the hybridization between $\mathrm{Pt}$ and $\mathrm{Ni}_{2} \mathrm{P}$ in the synthesis. Moreover, the presence of $\mathrm{Ni}_{2} \mathrm{P}$ favored $\mathrm{CO}$ oxidation due to its active role in water activation (i.e., by oxygen evolution reaction) [65], which collectively helped sustain the highly active and stable catalytic performance for EOR.

On the other hand, metal oxides have also emerged as promising additives that can enhance the catalytic performance for EOR. For example, tin oxides can help provide $\mathrm{OH}$ groups outside the surface by adsorbing and dissociating $\mathrm{H}_{2} \mathrm{O}$, which can reduce the formation of $\mathrm{CO}$ intermediates. On the basis of merits induced by both $\mathrm{Rh}$ and $\mathrm{SnO}_{2}$ [66], ultrathin $\mathrm{PtRh}$ nanowires patched with $\mathrm{SnO}_{2}$ were synthesized via a one-spot synthesis method [67]. The obtained $\mathrm{PtRh} @ \mathrm{SnO}_{2}$ nanowires had an average diameter of $\sim 2.0 \mathrm{~nm}$ (Figure $4 \mathrm{a}$ ) and exhibited the highest EOR activities at an optimal $\mathrm{SnO}_{2}$ content of 40.7 at $\%$. Moreover, the core-shell-like $\mathrm{PtRh} @ \mathrm{SnO}_{2}$ nanowires (Figure $4 \mathrm{a}-\mathrm{d}$ ) showed more advanced mass activity and specific activity $\left(3160 \mathrm{~mA} \mathrm{mg}^{-1}\right.$ and $5.63 \mathrm{~mA} \mathrm{~cm}^{-2}$, respectively) compared to commercial $\mathrm{Pt} / \mathrm{C}$ in alkaline electrolyte (Figure 4e). In addition to the widely-developed nanowires, many novel nanostructures, such as nanocages and nanoframes, have been constructed to accommodate more abundant active sites and large surface-area-to-volume ratios. Also, a few ternary metal-based catalysts (such as PtCuNi [68], PtRhNi [61], PtMoNi [69], and PtAuSn [70]) with precise composition control have shown increased EOR selectivity. The PtRhNi polyhedra nanoparticles [71] were chemically etched to form Pt-skin PtRhNi nanoframes which were then attached with $\mathrm{SnO}_{2}$ nanoparticles [61] (Figure 4f-i). The hybrid $\mathrm{SnO}_{2} @ \mathrm{PtRhNi} / \mathrm{C}$ catalysts exhibited excellent mass activity and specific activity that were 6-fold and 10-fold higher than the commercial $\mathrm{Pt} / \mathrm{C}$ catalyst, respectively (Figure 4j). The $\mathrm{CeO}_{2}$ addition also proved effective in enhancing the catalytic activity of Pt-based catalysts in EOR due to its interaction with $\mathrm{Pt}$ and the ability in oxygen storage [72,73]. Xu et al. adopted a simple electro-deposition method to prepare $\mathrm{CeO}_{2}$-modified $\mathrm{Pt} / \mathrm{Ni}$ catalysts which exhibited advanced catalytic performance for EOR in alkaline media [60]. This is mainly ascribed to the bifunctional mechanism, i.e., $\mathrm{CeO}_{2}$ can accelerate the oxidation of adsorbed $\mathrm{CO}$ on $\mathrm{Pt}$ surface by supplying chemisorbed oxygen species. 

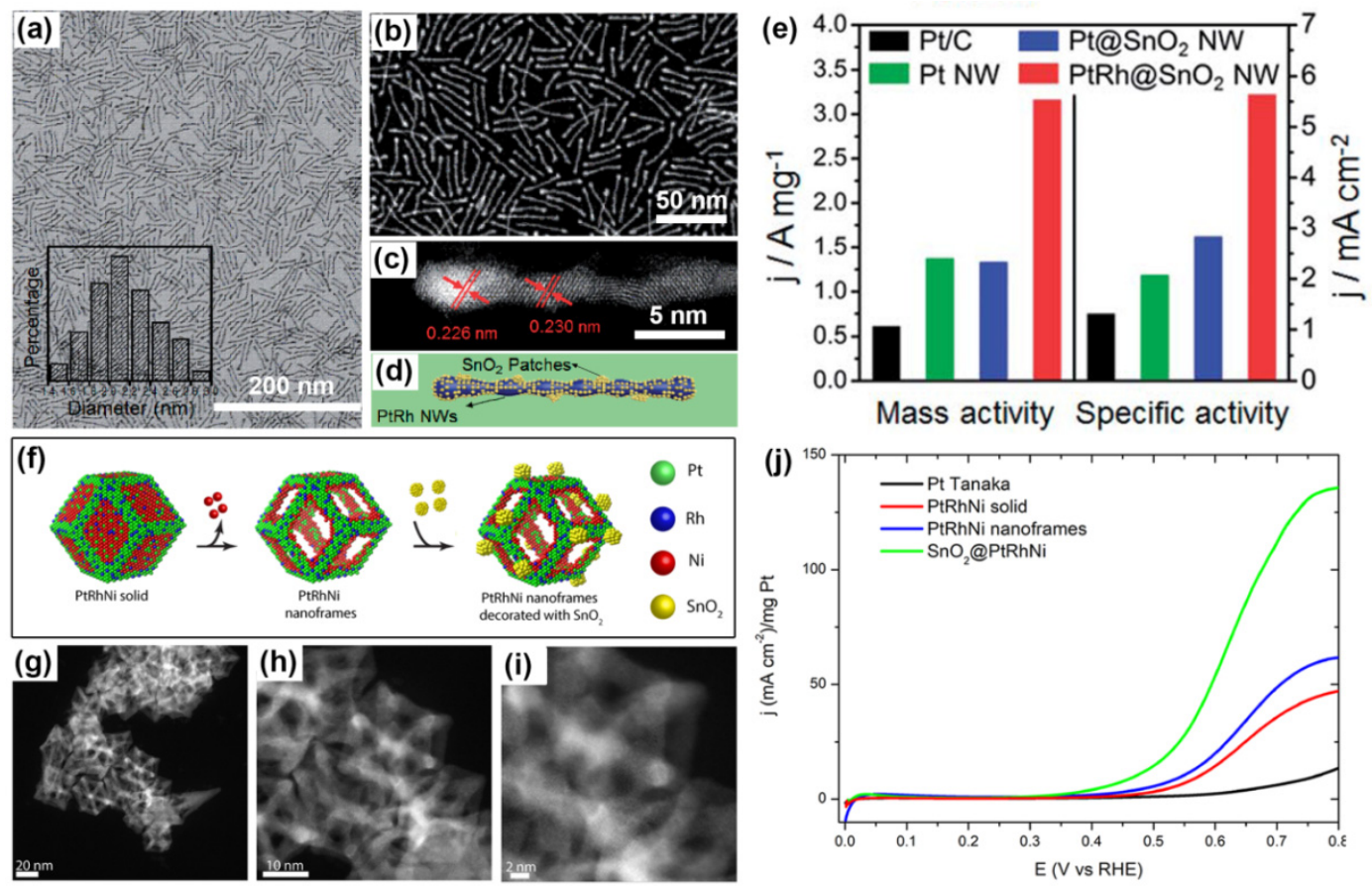
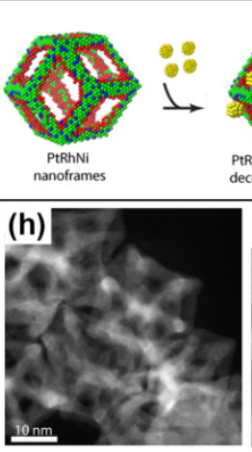
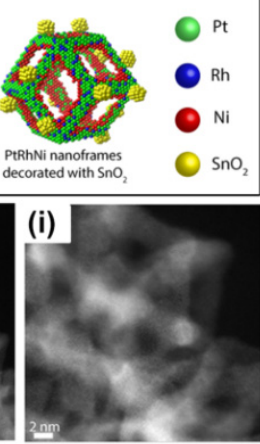

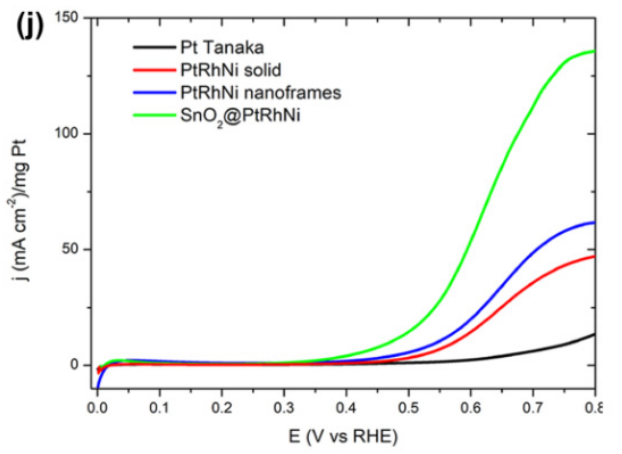

Figure 4. (a) TEM image, (b) HAADF-STEM (high-angle annular dark-field scanning transmission electron microscopy) image, (c) aberration-corrected HAADF-STEM image and (d) the structural model of ultrathin PtRh@SnO ${ }_{2}$ nanowires. The inset in (a) shows the average diameter of $\mathrm{PtRh}_{\mathrm{S}} \mathrm{SnO}_{2}$ nanowires. (e) The comparison of mass and specific activities of different catalysts for EOR. Reproduced with permission from [67]. Copyright 2019, Royal Society of Chemistry. (f) Schematic illustration for the synthesis of $\mathrm{SnO}_{2}$-decorated PtRhNi nanoframes. (g-i) HAADF-STEM images of the PtRhNi nanoframes with decoration of $\mathrm{SnO}_{2}$ nanoparticles. (j) Comparison of the first EOR forward scan of different catalysts recorded in $0.1 \mathrm{M} \mathrm{HClO}_{4}+0.5 \mathrm{M} \mathrm{C}_{2} \mathrm{H}_{5} \mathrm{OH}$ solution. Adapted with permission from [61]. Copyright 2019, American Chemical Society.

\subsection{Optimization of Support Materials}

Besides the extensive efforts devoted to the optimization of compositions and microstructures for catalysts, another method can be adopted for the further enhancement of catalytic activities, i.e., the regulation of support materials. In general, catalysts need to be coated on supports to realize their functionalizations for EOR. Carbon black (such as Vulcan XC-72R) often serves as the most common support material due to its high electrical and thermal conductivity, large surface area, low cost and easy availability. However, the inert nature of carbon prohibits its assistance in catalytic activities [74]. The surface area and electrical conductivity of supports as well as the dispersity of catalysts on supports are among the critical factors that affect the EOR at anodes [75]. Recent studies have been extended to develop diverse alternatives to replace the carbon black, such as carbon nanotubes, graphene, metal oxides, metal hydroxides, and their hybrids. Moreover, a few self-supported promoters have also been developed, such as $\mathrm{Fe}_{2} \mathrm{P}$ [59], $\mathrm{W}_{2} \mathrm{C}$ [70], and $\mathrm{MoS}_{2}$ [76]. Further, flexible and conductivity substrates can also serve as promising supports for Pt- and Pd-based catalysts. In the following section, the alternative support materials for catalysts during EOR will be covered.

\subsubsection{Carbon-Based Materials}

Carbon-based materials, including carbon black, expanded graphite, graphene and carbon nanotubes (CNTs) have long been regarded as typical support materials for the EOR catalysts due to their large specific areas, excellent chemical stability and strong affinity to catalysts. The strong affinity between metal catalysts and carbon-based supports may originate from the formation of possible metal-carbon bonding. In general, Vulcan XC-72R is the most popular commercial carbon black that 
has been widely used as support materials in Pt- and Pd-based catalysts [77]. However, the micropores on Vulcan XC-72R are usually below $2 \mathrm{~nm}$, making it hard for it to be completely interacted with most catalysts. In this regard, expanded graphite [78], graphene [79], carbon nanotubes [80], and their hybrids have aroused great interests which can promote the electrochemical activity of catalysts. Further, introducing various dopants and designing novel structures in the carbon-based materials serve as important strategies for further optimization of these support materials. Doping with suitable elements (such as B, N, S, or P) in carbon-based supports can increase the active sites inside and facilitate the modulation of conjugated bonds and thus electron distribution [81,82]. Moreover, many novel structures, such as hollow structures [83], nanocages [84], and porous structures [81], are incorporated in carbon-based supports with markedly enlarged surface areas and enhanced activities. Recently, ternary N, S, and P-doped hollow carbon sphere materials were synthesized and utilized as a promising support for $\mathrm{Pd}$ nanoparticles, which show a high mass peak current density of $1686 \mathrm{~mA} \mathrm{mg}_{\mathrm{Pd}}{ }^{-1}$ for EOR, nearly three times that of $\mathrm{Pd} / \mathrm{C}$ catalysts [83]. Similarly, graphitized carbon nanocage-supported Pd nanoparticles also show advanced catalytic activity and stability for EOR [84]. This is due to the unique graphite structure and opening gaps of carbon nanocages that facilitate electron transfer, mass transport, and ion diffusion. However, it should be noted that graphitic carbon-based support materials may suffer from corrosion under electrochemical oxidation conditions [85]. In particular, heteroatom-doped carbon nanostructures with abundant defects are quite sensitive to corrosion. This may result in the detachment, aggregation, or dissolution of active materials and thus the degradation of catalytic performance. Therefore, it becomes a necessity to investigate the durability of catalysts as well as to develop corrosion-resistant support materials during EOR.

In addition, CNTs have been widely explored as promising support materials for various catalysts in direct ethanol fuel cells [29]. As the integrated CNTs often show a chemically inert nature, surface treatment or chemical doping is necessary for CNTs to further enlarge their surface areas and to increase their affiliation with metal-based catalysts by introducing functionalized groups (such as the oxygen-containing group) on the surface [86]. For example, $\mathrm{HNO}_{3}$-treated $\mathrm{CNTs}$ were employed as the support material of Pt-based nanoparticles [31]. The obtained bimetallic PtAu/CNTs and $\mathrm{PtPd} / \mathrm{CNTs}$ catalysts exhibit large ECSAs, low onset potentials and excellent stabilities. Moreover, nitrogen-doping in CNTs has proved effective in advancing $\pi$-binding ability, introducing point defects, and improving interaction between CNT supports and active sites of catalysts [87]. Pd nanoparticles anchored on three-dimensional (3D) N-doped CNTs (denoted as Pd/3DNCNTs) were synthesized via a facile and green method using ethanol as the reducing agent [88], as presented in Figure 5a. The Pd/3DNCNTs catalysts show a much increased catalytic performance and durability towards EOR which benefits from the improved interaction between Pd nanoparticles and nitrogen-containing functional groups as well as the three-dimensional network structure (Figure 5b). Despite the unique advantages of CNTs, challenges still remain with regards to the self-dispersity of CNT as well as the homogeneous distribution of the catalyst within CNT networks. Moreover, Ning and coworkers developed a series of CNT-supported Pd-based catalysts, including Pd/CNT, bimetallic $\mathrm{PdSn} / \mathrm{CNT}$ and trimetallic PdSnNi/CNT via a microwave-assisted polyols and in-situ reduction [89]. The Pd-based nanoparticles were found to be well distributed on CNT support with no obvious aggregation (Figure $5 c$ ), thus securing a large electrochemically active surface area (ECSA). Together with the beneficial modification of electronic structures by $\mathrm{Sn}$ and $\mathrm{Ni}$ alloying, $\mathrm{PdSnNi/CNT}$ catalysts demonstrate enhanced electrocatalytic activity and long-term durability for the EOR in alkaline environment when compared to the $\mathrm{Pd} / \mathrm{C}$ catalyst. Moreover, carbon-based nanocomposites comprised of expanded graphite and multi-walled CNTs (Figure $5 \mathrm{~d}$ ) have also emerged as promising supports for $\mathrm{Pd}$ nanoparticle catalysts [36]. Further, $\mathrm{Pd}_{5}$ nanoclusters $(\sim 1 \mathrm{~nm})$ with an ultralow loading of $2 \%$ on multi-walled CNTs supports demonstrate superior catalytic activity toward EOR [80]. In particular, the mass activity for $\mathrm{Pd}_{5}$ nanoclusters/CNTs can reach $1.82 \mathrm{~mA} \mathrm{mg}_{\mathrm{Pd}}{ }^{-1}, \sim 2$ times higher than that of the commercial $\mathrm{Pd} / \mathrm{C}$. The onset and peak potential of $\mathrm{Pd}_{5}$ nanoclusters/CNTs is also reduced in comparison to that of $\mathrm{Pd} / \mathrm{C}$ catalysts. The great enhancement in the catalytic performance for EOR in 
CNT-supported $\mathrm{Pd}_{5}$ nanoclusters mainly benefits from the increased surface area-to-volume ratio as well as the improved exposure of active atoms.

(a)

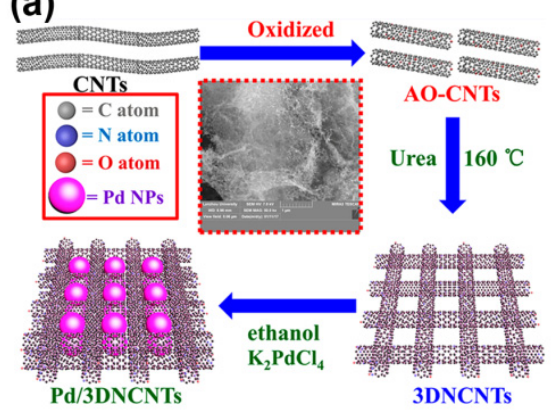

(b)

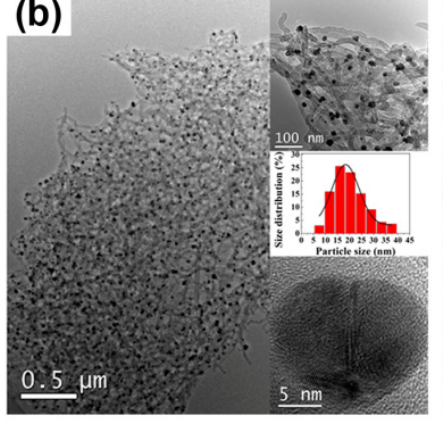

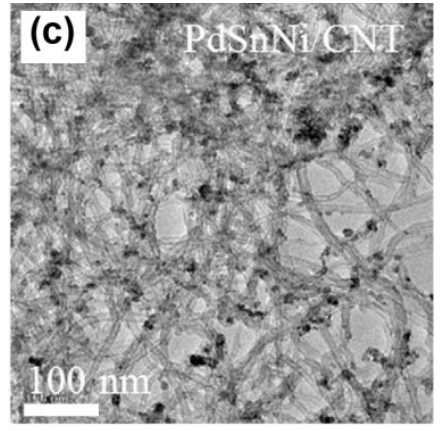

(f) ${ }^{90}$

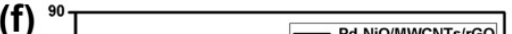

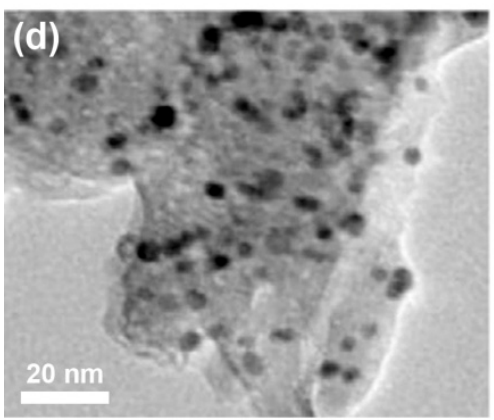
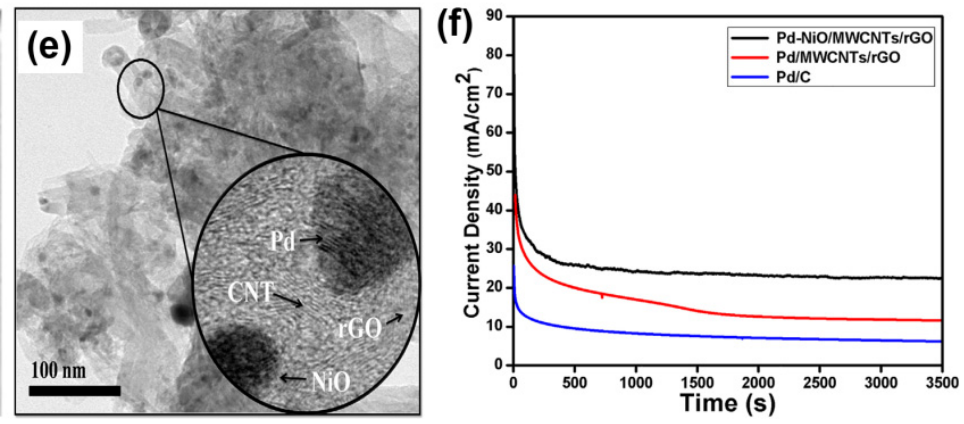

Figure 5. (a) Schematic synthetic route of Pd/3DNCNTs catalyst. (b) TEM image of Pd/3DNCNTs. The insets correspond to the size distribution histograms and high-resolution TEM images of the lattice structure of Pd nanoparticles. Reproduced with permission from [88]. Copyright 2018, American Chemical Society. (c) TEM image of well-distributed PdSnNi nanoparticles anchored on carbon nanotubes (CNTs). Reproduced with permission from [89]. Copyright 2019, Elsevier Ltd. (d) TEM image of Pd nanoparticles supported on expanded graphite and multi-walled CNTs. Reproduced with permission from [36]. Copyright 2018, Elsevier Ltd. (e) High-resolution TEM image of $\mathrm{Pd}-\mathrm{NiO} / \mathrm{CNTs} /$ reduced graphene oxide ( $\mathrm{rGO}$ ) hybrid catalysts with an enlarged view of the selected area, showing the presence of Pd, CNT and rGO. (f) Stability test of ethanol oxidation on Pd/multi-wall (MW)CNTs/rGO, Pd-NiO/MWCNTs/rGO and Pd/C electrodes. Reproduced with permission from [79]. Copyright 2018, Elsevier Ltd.

Furthermore, another two-dimensional allotrope of carbon, graphene or reduced graphene oxide (rGO), has been considered as an important support material in catalysts due to its high electron mobility, attractive mechanical flexibility, fascinating surface areas, advanced chemical stability, and facile dispersion with metal-based catalysts [90]. The Pt-based catalyst-decorated rGO nanosheets often possess more advanced catalytic behaviors in ethanol oxidation than carbon black-supported Pt [91]. Pd-based catalysts supported by rGO have also emerged as promising catalysts for EOR in alkaline solution [92,93]. For instance, Alfi et al. synthesized three-dimensional Pd-Cd nanonetworks supported by rGO by a galvanic method [94]. The obtained Pd-Cd/rGO catalysts show outstanding activity for EOR in alkaline media, i.e., a high peak current density of $179 \mathrm{~mA} \mathrm{~cm}^{-2}$ which is $\sim 4.5$ times higher than that of $\mathrm{Pd} / \mathrm{C}$ commercial catalysts. It is noteworthy that $\mathrm{rGO}$ nanosheets usually tend to form agglomerations in solution due to the $\pi-\pi$ interactions between adjacent nanosheets. This may result in reduced surface areas and electrical conductivity of rGO, making it difficult to maximize the catalytic activities of rGO supported metal-based catalyst. To overcome the detrimental effects caused by rGO agglomeration, CNTs attached with $\mathrm{Pd}-\mathrm{NiO}$ nanoparticles were fabricated and incorporated with rGO support (Figure 5e) [79]. The Pd-NiO/CNTs/rGO hybrid catalysts present much higher activity $\left(90.9 \mathrm{~mA} \mathrm{~cm}^{-2}\right)$ for EOR in alkaline solution than either hybrid Pd/CNTs/rGO $\left(43.1 \mathrm{~mA} \mathrm{~cm}^{-2}\right)$ or commercial $\mathrm{Pd} / \mathrm{C}$ catalysts $\left(28.0 \mathrm{~mA} \mathrm{~cm}{ }^{-2}\right)$. Also, the durability of the hybrid catalysts has been 
improved significantly (Figure $5 \mathrm{f}$ ). The great enhancement in the catalytic performance and stability for $\mathrm{Pd}-\mathrm{NiO} / \mathrm{CNTs} / \mathrm{rGO}$ mainly results from the increased active sites induced by the interaction between rGO and CNTs as well as the anti-poisoning effect derived from bimetallic Pd-NiO nanoparticles. In addition, another poly(triazine imide) (PTI) and graphene hybrid support have been developed and applied for Pt-Sn catalysts [95], which exhibit a more efficient performance towards EOR than graphene-supported counterparts. Therefore, it is essential to develop hybrid support materials by combining the synergistic effects from various carbon-based materials and other additives, thus boosting their applications in catalytic fields.

\subsubsection{Non-Carbon-Based Supports}

Considering that DEFCs usually exhibit increased efficiency of ethanol oxidation at elevated temperatures [96], it becomes critical to investigate the temperature-dependent catalytic activity for EOR. Also noteworthy is that most carbon-based support materials may corrode at high temperatures [97] or harsh environments [85], which significantly reduces the catalyst stability. Therefore, it is important to develop alternative support materials with high stability and corrosion resistance during the EOR process. Recently, many non-carbon-based support materials, such as metal oxides, hydroxides, carbides, and sulfides, have also received considerable research interests due to their additional contribution to catalytic performance and excellent stability in alkaline and/or acid solutions. Studies have found that the addition of metal oxides, for example $\mathrm{TiO}_{2}$, in catalysts can improve their long-term stability during ethanol oxidation [98]. In particular, $\mathrm{PdRu}$ nanocrystals supported on $\mathrm{TiO}_{2}$ exhibit ultrahigh stability towards EOR in alkaline electrolyte [32], which is owing to the collective effects of (i) incorporation of oxyphilic $\mathrm{Ru}$ in Pd-based catalysts, (ii) utilization of $\mathrm{TiO}_{2}$ as the support material, and (iii) interaction between $\mathrm{Ru}$ and $\mathrm{TiO}_{2}$. The scheme of the synergistic effects between $\mathrm{Ru}$ and $\mathrm{TiO}_{2}$ is presented in Figure 6a. As most metal oxides have inferior electrical conductivity, they are generally mixed with commercial carbon black (Vulcan XC-72R) to form composite supports, such as $\mathrm{MnO}_{2} /$ carbon black [77] and $\mathrm{Ni}-\mathrm{SiO}_{2} /$ carbon black [99] for the integration of efficient anode catalysts.

Transition metal carbides, especially $\mathrm{W}_{2} \mathrm{C}$ and $\mathrm{Mo}_{2} \mathrm{C}$, possess superior electrical conductivity and ultrahigh chemical and thermal stabilities and have been considered as promising support materials in electrocatalytic fields $[70,100,101]$. Ternary PtAuSn catalysts supported on $\mathrm{W}_{2} \mathrm{C}$ present much higher catalytic activities towards EOR in acid solution and at increasing temperatures of up to $70{ }^{\circ} \mathrm{C}$ when compared to PtAuSn/C catalysts [70]. This mainly benefits from the $\mathrm{W}_{2} \mathrm{C}$-induced bifunctional mechanism and the additional charge transfer from $\mathrm{W}_{2} \mathrm{C}$ support to alloy catalysts. Moreover, $\mathrm{Mo}_{2} \mathrm{C}$ nanoparticles-supported $\mathrm{Pd}$ catalysts also show advanced catalytic performance and durability for EOR in alkaline media [102]. Further, $\mathrm{Ni}$ insertion in $\mathrm{Mo}_{2} \mathrm{C}$ was found to suppress the aggregation of $\mathrm{Mo}_{2} \mathrm{C}$ nanoparticles. In addition, $\mathrm{MXene} \mathrm{has} \mathrm{emerged} \mathrm{as} \mathrm{a} \mathrm{promising} 2 \mathrm{D}$ material and support material for catalysts due to its outstanding stability and high electrical conductivity. The typical formula of MXene is $M_{n+1} X_{n} T_{x}$ where $M$ denotes a transition metal such as $M o, V, N b$, Ti and Ta, $X$ represents $C$ or $\mathrm{N}$, and $\mathrm{T}_{\mathrm{x}}$ refers to the functional groups on the surface such as $-\mathrm{O},-\mathrm{OH}$ and $-\mathrm{F}$ [15]. Wang et al. utilized $\mathrm{Ti}_{3} \mathrm{C}_{2} \mathrm{~T}_{\mathrm{x}}$ MXene nanosheets as the support materials of ternary porous PtRhFe nanospheres (denoted as PtRhFe-NPS@MXene) which show advanced activity and stability for EOR [28] (Figure 6d). The morphologies of MXene support and PtRhFe-NPS@MXene are shown in Figure 6b,c. Apart from the beneficial effects of porous structures and enhanced interaction between the MXene support and metal-based catalysts, the abundant termination groups on the MXene surface can promote the electron exchange with the PtRhFe alloys. 

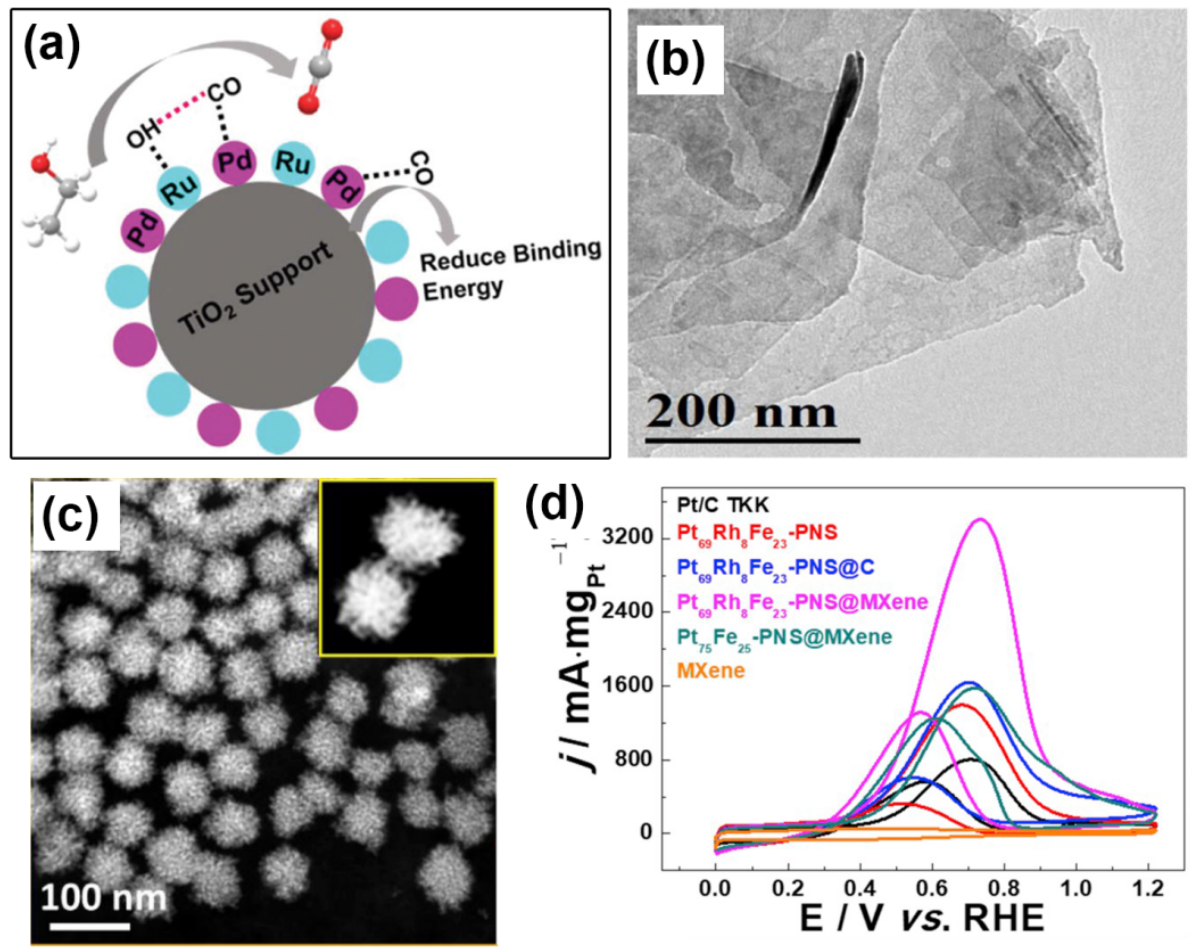

Figure 6. (a) The schematic diagram of the synergistic effects between $\mathrm{Ru}$ and $\mathrm{TiO}_{2}$. Reproduced with permission from [32]. Copyright 2019, Royal Society of Chemistry. (b) TEM image of the isolated $\mathrm{Ti}_{3} \mathrm{C}_{2} \mathrm{~T}_{\mathrm{x}}$ MXene nanosheets. (c) HAADF-STEM image of hybrid PtRhFe-NPS@MXene catalysts. (d) Cyclic voltammogram curves of as-prepared catalysts in $\mathrm{N}_{2}$-saturated with $1.0 \mathrm{M}$ ethanol solution. Reproduced with permission from [28]. Copyright 2019, Elsevier Ltd.

Another analogue of graphene, $\mathrm{MoS}_{2}$, has been explored as a support material in ethanol oxidation. The outer-layered sulfur atoms usually serve as the most active parts of $\mathrm{MoS}_{2}$ that can easily anchor metal-based nanoparticles, thus increasing the catalytic sites. Recently, $\mathrm{MoS}_{2}$ nanoflowers were synthesized as the support via a hydrothermal method, and were then subjected to the electrodeposition of $\mathrm{Pt}$ nanoparticles [76]. The obtained $\mathrm{Pt} / \mathrm{MoS}_{2}$ catalysts show larger ESCA and higher peak current density in comparison to commercial $\mathrm{Pt} / \mathrm{C}$. This can be attributed to reduced energy barrier in $\mathrm{MoS}_{2}$-supported $\mathrm{Pt}$ that facilitates ethanol dissociation as manifested by the calculation of density functional theory (DFT). Further, the 2D metal hydroxides, such as porous $\mathrm{Ni}(\mathrm{OH})_{2}$ nanoflakes, have evolved as promising support materials in Pt-based catalysts due to their high electrical conductivity and abundant active sites involved [34].

Additionally, porous non-noble metals, such as porous $\mathrm{Ni}, \mathrm{Ni}$ foam, and porous $\mathrm{Co}$, are also among the potential support materials for Pt- and Pd-based catalysts [46,103], as the porous features can favor the mass and electron transfer between catalysts and electrolytes. For instance, porous trimetallic PtRhCu nanoboxes fabricated via a galvanic reduction method (Figure 7a) exhibit superior catalytic activity and stability for EOR [98]. The EOR peak current for $\mathrm{Pt}_{54} \mathrm{Rh}_{4} \mathrm{Cu}_{42}$ nanoboxes reaches $4090 \mathrm{~mA} \mathrm{mg}_{\mathrm{N}}{ }^{-1}$ which is $\sim$-fold and 4-fold higher than that of $\mathrm{Pt}_{58} \mathrm{Cu}_{42}$ nanoboxes and commercial Pt black, respectively. The significant enhancement in the activity and durability of $\mathrm{Pt}_{54} \mathrm{Rh}_{4} \mathrm{Cu}_{42}$ nanoboxes mainly benefits from the synergistic effects of composition optimization and microstructure control. In particular, the hollow and porous structures (as shown in Figure $7 \mathrm{~b}, \mathrm{c}$ ) function as both support materials and active frameworks that facilitate the mass transfer and atomic utilization. Similar self-supported porous catalysts have also been reported recently, such as porous PdRh nanobowls (Figure 7d,e) synthesized by a facile one-pot hydrothermal method [103]. 

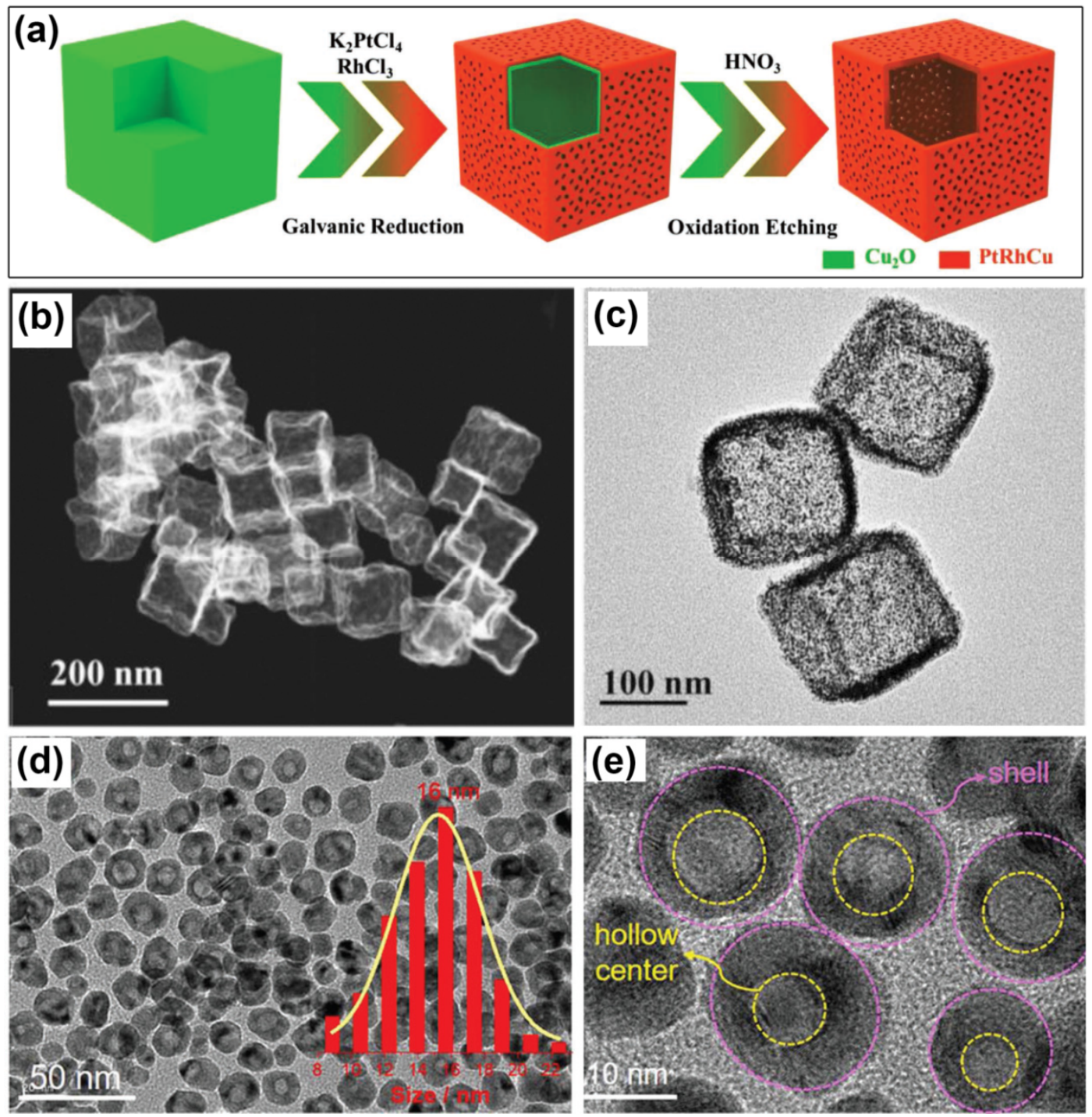

Figure 7. (a) Schematic diagram of the preparation process for PtRhCu nanoboxes. (b) HAADF-STEM image and (c) TEM image of PtRhCu trimetallic nanoboxes. Reproduced with permission from [98]. Copyright 2018, WILEY-VCH. (d,e) TEM images of PdRh nanobowls. The inset in (d) refers to the size distribution histogram. Reproduced with permission from [103]. Copyright 2019, The Royal Society of Chemistry.

Besides this, growing demands for flexible electrodes have arisen with the rapid development of wearable electronics. Most of the aforementioned studies focus on developing advanced catalysts supported by rigid electrodes. Recently, flexible electrodes have aroused great interests among the electrochemical community, such as the carbon cloth utilized as flexible electrodes in supercapacitor [104], hydrogen evolution [105], and ethanol oxidation [106]. The carbon fiber cloth-supported PdCo nanotube arrays have been synthesized as a promising high-performance flexible electrocatalysts with superior catalytic activity and stability during EOR [106]. Moreover, polydimethylsiloxane (PDMS), a widely used flexible substrate in electrochemistry, has been applied in ethanol oxidation recently. Ag nanowires with electro-deposited Pd were drop-casted on the PDMS substrate to achieve the $\mathrm{Pd} / \mathrm{Ag} / \mathrm{PDMS}$ flexible electrodes [25]. The schematic diagram for the preparation process is shown in Figure 8a. The uniformly distributed Pd nanoparticles on $\mathrm{Ag}$ nanowires (Figure $8 \mathbf{b}$ ) were found to accelerate the adsorption of active substances, which can further improve the charge transfer for EOR [27]. The flexible Pd/Ag/PDMS electrodes show stable current densities when 
subjected to bending or twisting for up to 2500 cycles (Figure 8c). The mechanical robustness feature empowers the flexible electrodes with broadened applications under harsh mechanical environments.
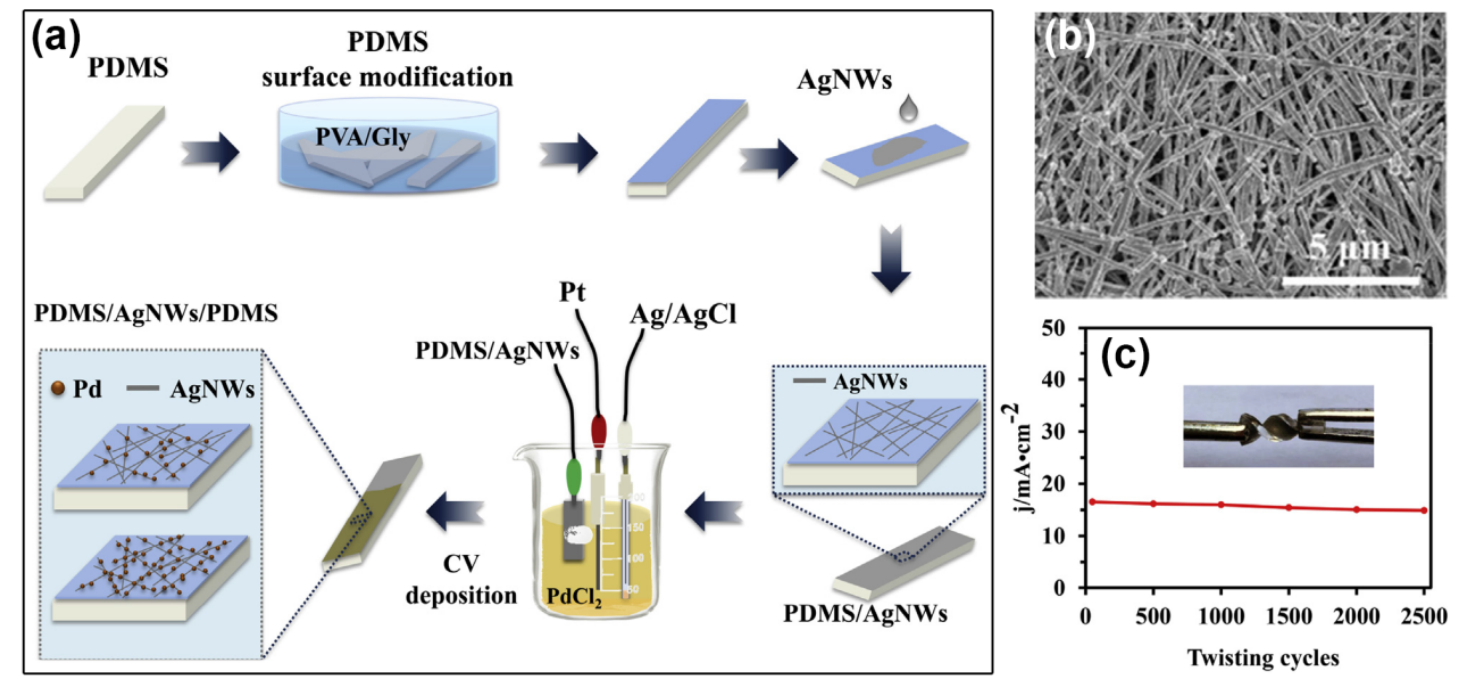

Figure 8. (a) Schematic illustration of the preparation process for Pd/Ag NWs/PDMS flexible electrodes. (b) SEM image of the Pd/AgNWs/PDMS electrodes deposited by cyclic voltammetry with an optimal cycle number of 25. (c) The peak specific oxidation current density (recorded in $0.1 \mathrm{M} \mathrm{KOH}$ and $1.0 \mathrm{M}$ ethanol solution at $0.55 \mathrm{~V}$ ) of the $\mathrm{CV}$ curve as a function of twisting cycles (with a fixed twisting angle of 720 degree) for the flexible Pd/Ag NWs/PDMS electrodes. The inset corresponds to the enlarged view of the twisting setup. Reproduced with permission from [25]. Copyright 2019, Hydrogen Energy Publications LLC.

\section{Development of Non-Noble Metal Catalysts for EOR}

As summarized above, intensive efforts have been directed to developing highly efficient and stable noble metal-based catalysts by composition control and structure modulation. When considering the practical application, the limited earth abundance and high cost become the main concerns for noble metal-based catalysts. To date, effective strategies, such as partial substitution of $\mathrm{Pt} / \mathrm{Pd}$ by non-noble metals and decreased loading via novel structure design, have been explored to reduce the overall cost of anode electrodes. For example, the favorable role of nickel incorporation in Pt-based catalysts is mainly attributed to the surface catalytic activity of Ni. Further, the complete replacement of noble metals with non-noble alternatives (such as $\mathrm{Fe}, \mathrm{Co}$, and $\mathrm{Ni}$ ) has found promising applications in ethanol oxidation due to the relatively high electrocatalytic activity and low cost [107-109].

Nickel metal is prone to surface oxidation and tends to form $\mathrm{NiOOH}$, especially in alkaline solution, which can promote the oxidation of CO adsorbed on the surface during EOR process [110]. Interested readers can refer to the comprehensive review on Ni-based catalysts for ethanol electro-oxidation [14]. Recently, a facile electrodeposition method has been used to prepare Ni nanoparticles as ethanol oxidation catalysts [111,112]. It was found that the $\mathrm{pH}$ value of the $\mathrm{NiSO}_{4}$ bath rather than the $\mathrm{Ni}$ ion concentration strongly affects the EOR activity of electrodeposited Ni nanostructures [111]. The Ni nanoparticles deposited on graphite electrode from a $\mathrm{pH}=5.5$ solution exhibit a current density of $1192 \mathrm{~mA} \mathrm{mg}^{-1}$ in alkaline solution. To avoid the possible agglomeration of Ni nanoparticles, an anionic surfactant, sodium dodecyl sulfate (SDS), was involved in the electrodeposition process [112]. When the SDS concentration equals to the critical micelle concentration (CMC), the obtained Ni nanoparticles are uniformly distributed. Another effective way to achieve uniformly grown Ni nanoparticles is the successive ionic layer adsorption and reaction (SILAR) method [113]. This can be applied for large-area growth of Ni nanoparticles on various substrates. In addition, Ni foam was employed as a substrate and subjected to in-situ electrodeposition of Au nanoparticles to form three-dimensional (3D) interconnected Ni/Au foams [110] (Figure 9a-c). The porous Ni foam/Au composite catalysts exhibit 
greatly improved catalytic activity for EOR when compared to Ni foam without Au and Ni foil with Au deposition. This mainly benefits from the high surface area of Ni foam and the advanced catalytic behavior of Au nanoparticles. Moreover, porous Ni phosphate has been synthesized and used as an efficient catalyst for EOR in alkaline media [114,115].

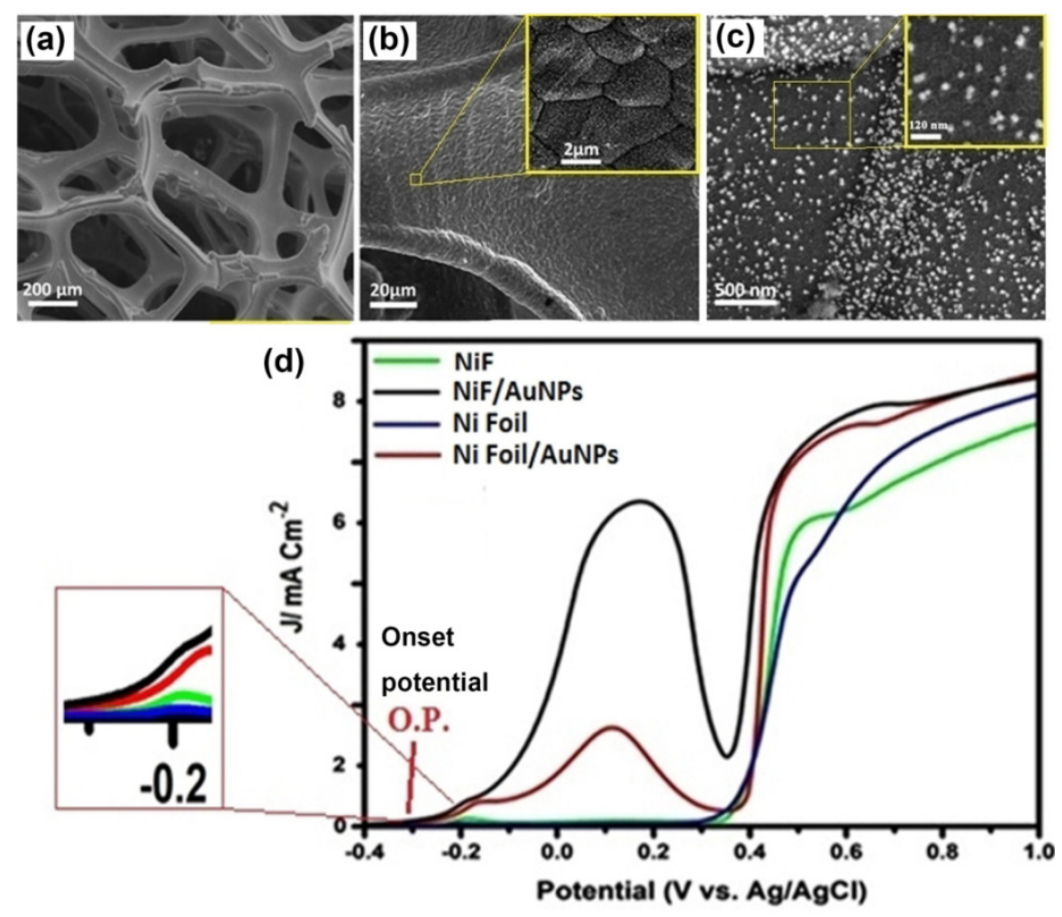

Figure 9. SEM images of (a) 3D Ni foam, and $(b, c) 3 D$ Ni foam decorated with Au nanoparticles. (a) The typical open-pore cellular structure of Ni foam. (b) The strut structure consists of equalized grains with an average size of $\sim 10 \mu \mathrm{m}$. (c) Further zoom-in image shows the strut surface decorated with Au nanoparticles by the electrochemical deposition method. The inset demonstrates the uniformly and separately distributed spherical Au nanoparticles. (d) Linear sweep voltammetry of electro-catalytic activity of Ni-based electrodes in $0.5 \mathrm{M} \mathrm{NaOH}$ solution containing $1.0 \mathrm{M}$ ethanol. The inset reveals the enlarged view of onset potential. Reproduced with permission from [110]. Copyright 2018, Wiley-VCH.

Other non-precious alloys based on Co and Fe alloys have also attracted considerable attention. As pristine cobalt is poor in the catalytic performance for fuel cells, it is usually incorporated with other metals (such as Ni [109], Fe [116], Cd [108] and Cr [117]) to form co-catalysts for ethanol electro-oxidation. For example, Cd-doped Co nanoparticles encapsulated in graphite shells were synthesized through a sol-gel method combined with calcination at high temperatures [108] (Figure 10a). The obtained $\mathrm{CoCd} / \mathrm{C}$ nanoparticles exhibited a significant improvement in the current density over pristine $\mathrm{Co} / \mathrm{C}$ and $\mathrm{Pt} / \mathrm{C}$ when used as electrocatalysts for EOR in basic media (Figure 10b). The enhanced activity towards EOR is probably favored by the formation of cadmium oxide layers on the catalyst surface that can transform to electroactive $\mathrm{CdOOH}$ in alkaline solution. Moreover, electrospinning together with calcination was employed to produce CoCr nanoparticles supported on carbon nanofibers [117]. A current density of $105 \mathrm{mAcm}^{-2}$ was attained for $\mathrm{CoCr} / \mathrm{C}$ catalysts with an optimized concentration of $10 \mathrm{wt} \% \mathrm{Cr}$. In addition, trimetallic FeCoNi [116] and CoNiMo [118] have been developed as promising anode catalysts for EOR. Nakamura et al. synthesized FeCoNi/carbon black via the impregnation method and employed them as anode catalysts in DEFCs [116]. The FeCoNi/carbon black catalysts presented the highest current density and the smallest crystalline size, indicating the positive correlation between EOR activity and amount of active sites on the surface. In contrast to the high temperature annealing $\left(1100^{\circ} \mathrm{C}\right)$ required for the impregnation method, a simple and low-cost electroless deposition was carried out below $100^{\circ} \mathrm{C}$ to prepare CoNiMo catalysts on Pd-catalyzed carbon 
substrates (CCS) [118]. The CoNiMo/CCS catalysts demonstrated irreversible ethanol electro-oxidation behavior in alkaline solution. Their catalyst activities for EOR mainly benefited from the deposited $\mathrm{Co}, \mathrm{Ni}$, and Mo elements, and the contribution from trace amounts of Pd in the support material can be neglected. Also, the deposited trimetallic catalysts showed more advanced catalytic performance for EOR than the bimetallic and monometallic catalysts. Furthermore, except for the important role of additives in $\mathrm{Pt}$ - and Pd-based catalysts, non-noble metal oxides can also serve as promising candidates for ethanol oxidation in DEFCs. The hierarchical $\mathrm{TiO}_{2} / \mathrm{ZnO}$ nanostructures (Figure 10c) fabricated by electrospinning and hydrothermal method showed a current density of $37 \mathrm{mAcm}^{-2}$ during EOR [119]. The catalytic performance was mainly influenced by the chemical composition and the fine nanostructures composed of $\mathrm{ZnO}$ nano-branches attached on $\mathrm{TiO}_{2}$ nanofibers. Besides, mesoporous $\mathrm{NiCo}_{2} \mathrm{O}_{4}$ fibers [120] (Figure 10d,e) and $\mathrm{NiCo}_{2} \mathrm{O}_{4} / \mathrm{CNT}$ aerogels [121] also exhibited the ability of ethanol oxidation in alkaline media.
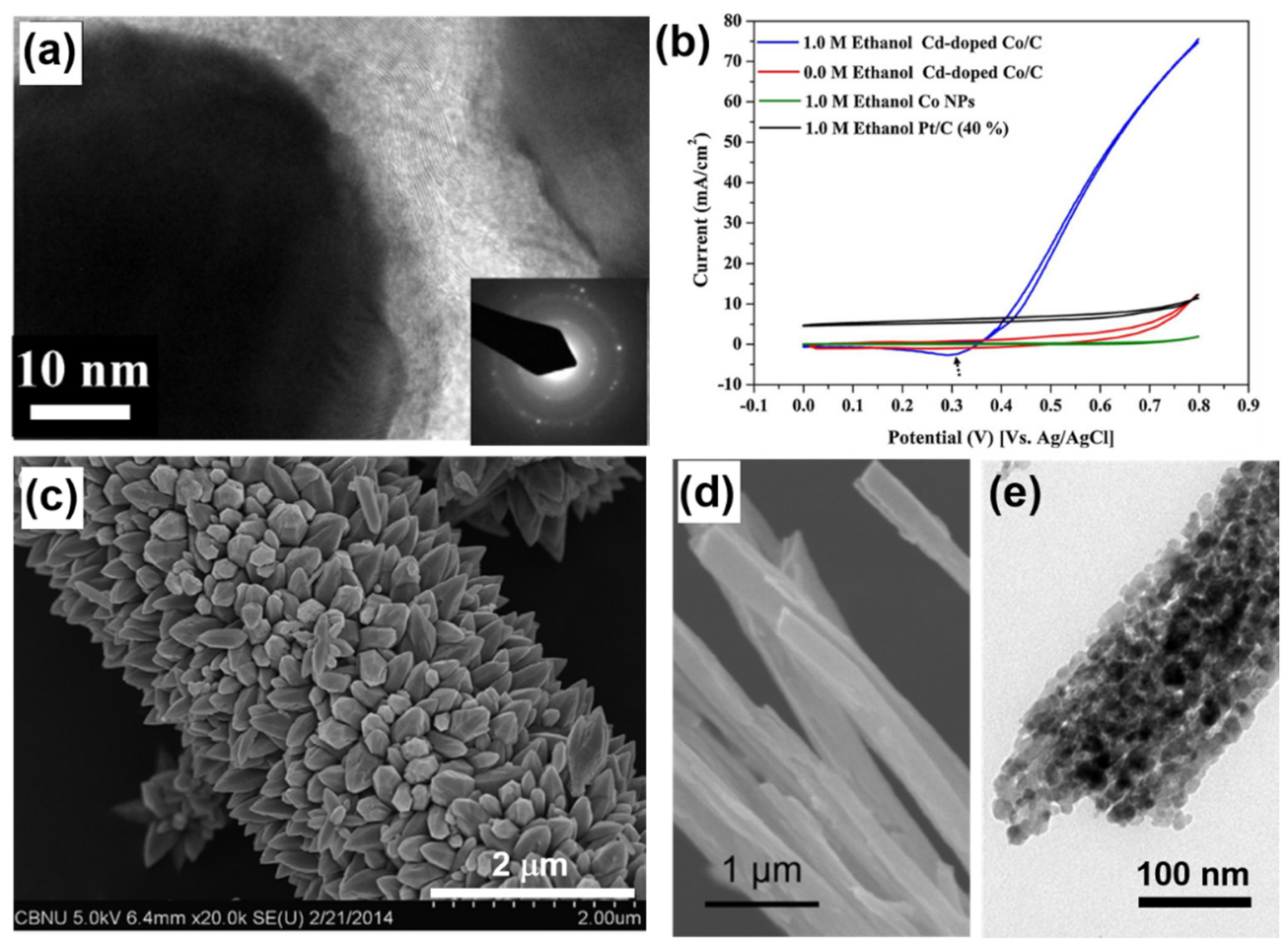

Figure 10. (a) TEM image of $\mathrm{CoCd} / \mathrm{C}$ nanostructures. The inset is the selected-area electron diffraction pattern of the nanoparticle; (b) cyclic voltammograms for Cd-doped $\mathrm{Co} / \mathrm{C}$ catalysts, $\mathrm{Pt} / \mathrm{C}(40 \%)$ and pristine cobalt nanoparticles in $1 \mathrm{M} \mathrm{KOH}$ solution with $1.0 \mathrm{M}$ ethanol. Reproduced with permission from [108]. Copyright 2013, Elsevier B.V. (c) SEM image of hierarchical $\mathrm{TiO}_{2} / \mathrm{ZnO}$ nanostructures. Reproduced with permission [119]. Copyright 2014, The editorial office of Journal of Materials Science \& Technology. (d) SEM image and (e) TEM image of mesoporous $\mathrm{NiCO}_{2} \mathrm{O}_{4}$ fibers. Reproduced with permission from [120].

\section{Outlook and Conclusions}

DEFCs have shown unique and attractive advantages over methanol- or hydrogen-based fuel cells, including abundant sources of ethanol fuel that can be produced from various crops (such as wheat, sugar-cane, and corn), high energy density of fuels, and relatively low costs in fuel storage and transportation. In comparison to power generators based on traditional fossil fuels, DEFCs can significantly reduce the emission of greenhouse gases. These features make DEFCs promising power devices for applications in portable electronics, transportation fields, and remote areas. The current review summarizes the recent advances in anodic nanocatalysts for ethanol electro-oxidation that are mainly based on state-of-the-art Pt, Pd, and non-noble metals. The implementation of both 
composition and microstructure control plays important roles in promoting the electrocatalytic activity and durability of various candidates for EOR. Furthermore, in combination with the optimization, many hybrid catalysts have been developed for promising applications in DEFCs [70]. Despite the significant progress achieved, the anode catalysts for ethanol electro-oxidation still suffer from low efficiency and durability in converting ethanol to $\mathrm{CO}_{2}$, thereby leaving much room for further improvement to accommodate the commercial application of DEFCs. The future development and research concerns of ethanol oxidation may be directed to the following:

Considering the intricate byproducts produced in EOR, it is critical to utilize in-situ test and observation tools to reveal the dynamic reaction processes, including in-situ Fourier transform infrared spectroscopy (FTIRS), on-line differential electrochemical mass spectrometry (DEMS) and in-situ Raman spectroscopy $[70,75]$.

More efforts should be directed to improving the long-term stability of anode catalysts in DEFCs. Although hybrid architecture design has emerged as an effective strategy to achieve homogeneously distributed catalysts on support materials, long-period cycling test often results in the inferior contact between catalysts and support materials. Therefore, post-analysis on morphology and composition is also required to understand the durability of a catalyst during EOR.

Investigating the temperature-dependent activity of catalysts for ethanol oxidation and finding out the optimized operational temperature at which the catalysts exhibit the highest conversion efficiency is also important. Further, it is vital to study the practical service performance by including more complex factors, such as variations of environment temperature and humidity.

Author Contributions: Y.Z. wrote the first draft of the manuscript. X.W., X.C. and K.C. contributed with the literature search and illustrations. Z.L. and Z.D. conceived the project. All authors contributed to manuscript revision, read and approved the submitted version. All authors have read and agreed to the published version of the manuscript.

Funding: This research was jointly funded by National Natural Science Foundation of China (Grant Nos. 51872127 and 51802252), Hubei Provincial Natural Science Foundation of China (No. 2018CFB271), Natural Science Foundation of Jiangsu Province (No. BK20180237), 111 Project 2.0 by China (No. BP2018008), and Fundamental Research Funds for the Central Universities (No. xjj2018001).

Conflicts of Interest: The authors declare no conflict of interest.

\section{References}

1. Akhairi, M.; Kamarudin, S.K. Catalysts in direct ethanol fuel cell (DEFC): An overview. Int. J. Hydrogen Energy 2016, 41, 4214-4228. [CrossRef]

2. Li, X.; Faghri, A. Review and advances of direct methanol fuel cells (DMFCs) part I: Design, fabrication, and testing with high concentration methanol solutions. J. Power Sources 2013, 226, 223-240. [CrossRef]

3. Jin, L.; Xu, H.; Chen, C.; Shang, H.; Wang, Y.; Wang, C.; Du, Y. Porous Pt-Rh-Te nanotubes: An alleviated poisoning effect for ethanol electrooxidation. Inorg. Chem. Front. 2020. [CrossRef]

4. Ross, D.K. Hydrogen storage: The major technological barrier to the development of hydrogen fuel cell cars. Vacuum 2006, 80, 1084-1089. [CrossRef]

5. Azam, A.M.I.N.; Lee, S.H.; Masdar, M.S.; Zainoodin, A.M.; Kamarudin, S.K. Parametric study on direct ethanol fuel cell (DEFC) performance and fuel crossover. Int. J. Hydrogen Energy 2019, 44, 8566-8574. [CrossRef]

6. Corti, H.R.; Gonzalez, E.R. Direct Alcohol Fuel Cells: Materials, Performance, Durability and Applications; Springer: New York, NY, USA, 2014.

7. Braunchweig, B.; Hibbitts, D.; Neurock, M.; Wieckowski, A. Electrocatalysis: A direct alcohol fuel cell and surface science perspective. Catal. Today 2013, 202, 197-209. [CrossRef]

8. Chauhan, R.; Srivastava, V. Advances in Electrocatalyst for Ethanol Electro-Oxidation. Nanomater. Alcohol Fuel Cells 2019, 49, 293-320.

9. Marinkovic, N.S.; Li, M.; Adzic, R.R. Pt-Based Catalysts for Electrochemical Oxidation of Ethanol. Top. Curr. Chem. 2019, 377, 11. [CrossRef] 
10. Badwal, S.P.S.; Giddey, S.; Kulkarni, A.; Goel, J.; Basu, S. Direct ethanol fuel cells for transport and stationary applications-A comprehensive review. Appl. Energy 2015, 145, 80-103. [CrossRef]

11. Camara, G.A.; Iwasita, T. Parallel pathways of ethanol oxidation: The effect of ethanol concentration. J. Electroanal. Chem. 2005, 578, 315-321. [CrossRef]

12. Ren, X.; Lv, Q.; Liu, L.; Liu, B.; Wang, Y.; Liu, A.; Wu, G. Current progress of Pt and Pt-based electrocatalysts used for fuel cells. Sustain. Energy Fuels 2020, 4, 15-30. [CrossRef]

13. Zhang, B.-W.; Yang, H.-L.; Wang, Y.-X.; Dou, S.-X.; Liu, H.-K. A Comprehensive Review on Controlling Surface Composition of Pt-Based Bimetallic Electrocatalysts. Adv. Energy Mater. 2018, 8, 1703597. [CrossRef]

14. Vyas, A.N.; Saratale, G.D.; Sartale, S.D. Recent developments in nickel based electrocatalysts for ethanol electrooxidation. Int. J. Hydrogen Energy 2019. [CrossRef]

15. Naguib, M.; Mochalin, V.N.; Barsoum, M.W.; Gogotsi, Y. 25th Anniversary Article: MXenes: A New Family of Two-Dimensional Materials. Adv. Mater. 2014, 26, 992-1005. [CrossRef] [PubMed]

16. Wang, L.-L.; Wang, Y.; Liao, W.-P.; Suo, Z.-h. Ethanol electrocatalytic oxidation performance of carbon black-supported Pt-Sn bimetallic catalysts. J. Mol. Catal. 2014, 39, 35-44.

17. Wu, F.; Zhang, L.; Lai, J.; Niu, W.; Luque, R.; Xu, G. PtCu-O highly excavated octahedral nanostructures built with nanodendrites for superior alcohol electrooxidation. J. Mater. Chem. A 2019, 7, 8568-8572. [CrossRef]

18. Bai, P.; Tian, F.; Wang, H.; Yang, T.; Bi, X.; Chai, Z.; Wang, X. Electrocatalytic Enhancement of 0D/1D/2D Multidimensional PtCo Alloy@Cobalt Benzoate/Graphene Composite Catalyst for Alcohol Electro-Oxidation. Adv. Mater. Interfaces 2019, 6, 1900946. [CrossRef]

19. Yuan, X.; Jiang, X.; Cao, M.; Chen, L.; Nie, K.; Zhang, Y.; Xu, Y.; Sun, X.; Li, Y.; Zhang, Q. Intermetallic PtBi core/ultrathin Pt shell nanoplates for efficient and stable methanol and ethanol electro-oxidization. Nano Res. 2019, 12, 429-436. [CrossRef]

20. Ahmad, Y.H.; Mohamed, A.T.; Youssef, K.M.; Kundu, S.; Mkhoyan, K.A.; Al-Qaradawi, S.Y. Rational synthesis of ternary PtIrNi nanocrystals with enhanced poisoning tolerance for electrochemical ethanol oxidation. Electrochem. Commun. 2019, 101, 61-67. [CrossRef]

21. Torrero, J.; Montiel, M.; Peña, M.A.; Ocón, P.; Rojas, S. Insights on the electrooxidation of ethanol with Pd-based catalysts in alkaline electrolyte. Int. J. Hydrogen Energy 2019, 44, 31995-32002. [CrossRef]

22. Zhu, Y.; Bu, L.; Shao, Q.; Huang, X. Subnanometer PtRh Nanowire with Alleviated Poisoning Effect and Enhanced C-C Bond Cleavage for Ethanol Oxidation Electrocatalysis. ACS Catal. 2019, 9, 6607-6612. [CrossRef]

23. Xu, Y.; Cui, X.; Qi, K.; Wei, S.; Wang, Q.; Zheng, W. Interface engineered surface morphology evolution of Au@Pd core-shell nanorods. Nanoscale 2018, 10, 21161-21167. [CrossRef] [PubMed]

24. Zhang, W.; Yang, Y.; Huang, B.; Lv, F.; Wang, K.; Li, N.; Luo, M.; Chao, Y.; Li, Y.; Sun, Y.; et al. Ultrathin PtNiM (M = Rh, Os, and Ir) Nanowires as Efficient Fuel Oxidation Electrocatalytic Materials. Adv. Mater. 2019, 31, 1805833. [CrossRef]

25. Sun, J.; Li, Y.; Liu, Y.; Zhou, W.; Zhen, X.; Lang, M.-F. Facile fabrication of a flexible electrode by electrodeposition of palladium on silver nanowires for ethanol oxidation. Int. J. Hydrogen Energy 2019, 44, 5990-5996. [CrossRef]

26. Lv, H.; Sun, L.; Xu, D.; Suib, S.L.; Liu, B. One-pot aqueous synthesis of ultrathin trimetallic PdPtCu nanosheets for the electrooxidation of alcohols. Green Chem. 2019, 21, 2367-2374. [CrossRef]

27. Benipal, N.; Qi, J.; Liu, Q.; Li, W. Carbon nanotube supported PdAg nanoparticles for electrocatalytic oxidation of glycerol in anion exchange membrane fuel cells. Appl. Catal. B Environ. 2017, 210, 121-130. [CrossRef]

28. Wang, P.; Cui, H.; Wang, C. In situ formation of porous trimetallic PtRhFe nanospheres decorated on ultrathin MXene nanosheets as highly efficient catalysts for ethanol oxidation. Nano Energy 2019, 66, 104196. [CrossRef]

29. Akbari, E.; Buntat, Z. Benefits of using carbon nanotubes in fuel cells: A review. Int. J. Energy Res. 2017, 41, 92-102. [CrossRef]

30. Rao, L.; Jiang, Y.-X.; Zhang, B.-W.; Cai, Y.-R.; Sun, S.-G. High activity of cubic PtRh alloys supported on graphene towards ethanol electrooxidation. Phys. Chem. Chem. Phys. 2014, 16, 13662-13671. [CrossRef]

31. Themsirimongkon, S.; Sarakonsri, T.; Lapanantnoppakhun, S.; Jakmunee, J.; Saipanya, S. Carbon nanotube-supported Pt-Alloyed metal anode catalysts for methanol and ethanol oxidation. Int. J. Hydrogen Energy 2019, 44, 30719-30731. [CrossRef] 
32. Liu, X.; Ning, L.; Deng, M.; Wu, J.; Zhu, A.; Zhang, Q.; Liu, Q. Self-recoverable Pd-Ru/TiO 2 nanocatalysts with ultrastability towards ethanol electrooxidation. Nanoscale 2019, 11, 3311-3317. [CrossRef] [PubMed]

33. García-Mateos, F.J.; Cordero-Lanzac, T.; Berenguer, R.; Morallón, E.; Cazorla-Amorós, D.; Rodríguez-Mirasol, J.; Cordero, T. Lignin-derived Pt supported carbon (submicron)fiber electrocatalysts for alcohol electro-oxidation. Appl. Catal. B Environ. 2017, 211, 18-30. [CrossRef]

34. Yan, Z.; Lu, M.; Li, Q.; An, L.; Xu, Z.; Zhu, L. Efficient Ni $(\mathrm{OH})_{2}$ Supported Ultra-Low Content of Pt Electrocatalyst for Ethanol Oxidation in Alkaline Solution. Curr. Nanosci. 2019, 15, 242-247. [CrossRef]

35. Valério Neto, E.S.; Gomes, M.A.; Salazar-Banda, G.R.; Eguiluz, K.I.B. Pt and Pt-Rh nanowires supported on carbon and $\mathrm{SnO}_{2}$ : $\mathrm{Sb}$ nanoparticles for ethanol electrochemical oxidation in acidic media. Int. J. Hydrogen Energy 2018, 43, 178-188. [CrossRef]

36. Li, H.; Zhang, Y.; Wan, Q.; Li, Y.; Yang, N. Expanded graphite and carbon nanotube supported palladium nanoparticles for electrocatalytic oxidation of liquid fuels. Carbon 2018, 131, 111-119. [CrossRef]

37. Abdelkareem, M.A.; Sayed, E.T.; Mohamed, H.O.; Obaid, M.; Rezk, H.; Chae, K.-J. Nonprecious anodic catalysts for low-molecular-hydrocarbon fuel cells: Theoretical consideration and current progress. Prog. Energy Combust. Sci. 2020, 77, 100805. [CrossRef]

38. Bai, J.; Liu, D.; Yang, J.; Chen, Y. Nanocatalysts for Electrocatalytic Oxidation of Ethanol. ChemSusChem 2019, 12, 2117-2132. [CrossRef]

39. Wang, Y.; Zou, S.; Cai, W.-B. Recent advances on electro-oxidation of ethanol on Pt-and Pd-based catalysts: From reaction mechanisms to catalytic materials. Catalysts 2015, 5, 1507-1534. [CrossRef]

40. Huang, D.-B.; Yuan, Q.; He, P.-L.; Wang, K.; Wang, X. A facile and general strategy for the synthesis of porous flowerlike Pt-based nanocrystals as effective electrocatalysts for alcohol oxidation. Nanoscale 2016, 8, 14705-14710. [CrossRef]

41. Chen, J.-Y.; Lim, S.-C.; Kuo, C.-H.; Tuan, H.-Y. Sub-1 nm PtSn ultrathin sheet as an extraordinary electrocatalyst for methanol and ethanol oxidation reactions. J. Colloid Interface Sci. 2019, 545, 54-62. [CrossRef]

42. Xu, Y.; Cui, X.; Wei, S.; Zhang, Q.; Gu, L.; Meng, F.; Fan, J.; Zheng, W. Highly active zigzag-like Pt-Zn alloy nanowires with high-index facets for alcohol electrooxidation. Nano Res. 2019, 12, 1173-1179. [CrossRef]

43. Rizo, R.; Sebastián, D.; Lázaro, M.J.; Pastor, E. On the design of Pt-Sn efficient catalyst for carbon monoxide and ethanol oxidation in acid and alkaline media. Appl. Catal. B Environ. 2017, 200, 246-254. [CrossRef]

44. Li, L.; Liu, H.; Qin, C.; Liang, Z.; Scida, A.; Yue, S.; Tong, X.; Adzic, R.R.; Wong, S.S. Ultrathin Pt $\mathrm{t}_{\mathrm{x}} \mathrm{Sn}_{1-\mathrm{x}}$ Nanowires for Methanol and Ethanol Oxidation Reactions: Tuning Performance by Varying Chemical Composition. ACS Appl. Nano Mater. 2018, 1, 1104-1115. [CrossRef]

45. Geng, X.; Cen, Y.; Sisson, R.; Liang, J. An effective approach towards the immobilization of PtSn nanoparticles on noncovalent modified multi-walled carbon nanotubes for ethanol electrooxidation. Energies 2016, 9, 165. [CrossRef]

46. Mattarozzi, L.; Cattarin, S.; Comisso, N.; Gerbasi, R.; Guerriero, P.; Musiani, M.; Vázquez-Gómez, L. Preparation of compact and porous Pd-Ni alloys and study of their performances for ethanol oxidation in alkali. Electrochim. Acta 2019, 307, 503-511. [CrossRef]

47. Cermenek, B.; Ranninger, J.; Feketeföldi, B.; Letofsky-Papst, I.; Kienzl, N.; Bitschnau, B.; Hacker, V. Novel highly active carbon supported ternary PdNiBi nanoparticles as anode catalyst for the alkaline direct ethanol fuel cell. Nano Res. 2019, 12, 683-693. [CrossRef]

48. Obradović, M.D.; Stančić, Z.M.; Lačnjevac, U.Č.; Radmilović, V.V.; Gavrilović-Wohlmuther, A.; Radmilović, V.R.; Gojković, S.L. Electrochemical oxidation of ethanol on palladium-nickel nanocatalyst in alkaline media. Appl. Catal. B Environ. 2016, 189, 110-118. [CrossRef]

49. Fontes, E.H.; Ramos, C.E.D.; Nandenha, J.; Piasentin, R.M.; Neto, A.O.; Landers, R. Structural analysis of $\mathrm{PdRh} / \mathrm{C}$ and $\mathrm{PdSn} / \mathrm{C}$ and its use as electrocatalysts for ethanol oxidation in alkaline medium. Int. J. Hydrogen Energy 2019, 44, 937-951. [CrossRef]

50. Geraldes, A.N.; Furtunato da Silva, D.; Martins da Silva, J.C.; Antonio de Sá, O.; Spinacé, E.V.; Neto, A.O.; Coelho dos Santos, M. Palladium and palladium-tin supported on multi wall carbon nanotubes or carbon for alkaline direct ethanol fuel cell. J. Power Sources 2015, 275, 189-199. [CrossRef]

51. Huang, W.; Kang, X.; Xu, C.; Zhou, J.; Deng, J.; Li, Y.; Cheng, S. 2D PdAg alloy nanodendrites for enhanced ethanol electroxidation. Adv. Mater. 2018, 30, 1706962. [CrossRef] 
52. Douk, A.S.; Saravani, H.; Farsadrooh, M.; Noroozifar, M. An environmentally friendly one-pot synthesis method by the ultrasound assistance for the decoration of ultrasmall Pd-Ag NPs on graphene as high active anode catalyst towards ethanol oxidation. Ultrason. Sonochem. 2019, 58, 104616. [CrossRef] [PubMed]

53. Silva, L.S.R.; Almeida, C.V.S.; Meneses, C.T.; Batista, E.A.; Santos, S.F.; Eguiluz, K.I.B.; Salazar-Banda, G.R. $\mathrm{AuPd} / \mathrm{C}$ core-shell and alloy nanoparticles with enhanced catalytic activity toward the electro-oxidation of ethanol in alkaline media. Appl. Catal. B Environ. 2019, 251, 313-325. [CrossRef]

54. Meléndez-González, P.C.; Sánchez-Castro, M.E.; Alonso-Lemus, I.L.; Pérez-Hernández, R.; Escobar-Morales, B.; Garay-Tapia, A.M.; Rodríguez-Varela, F.J. Highly Active Pd-CeO2-NR/C (Cerium Oxide Nanorods) Bifunctional Nanocatalysts with Remarkable Stability for the Ethanol Oxidation and Oxygen Reduction Reactions in Alkaline Media. ECS Trans. 2019, 92, 671-678. [CrossRef]

55. Zhou, Y.; Niu, M.; Zhu, S.; Liang, Y.; Cui, Z.; Yang, X.; Inoue, A. Preparation and electrocatalytic performance of nanoporous $\mathrm{Pd} / \mathrm{Sn}$ and $\mathrm{Pd} / \mathrm{Sn}-\mathrm{CuO}$ composite catalysts. Electrochim. Acta 2019, 296, 397-406. [CrossRef]

56. Huang, W.; Ma, X.Y.; Wang, H.; Feng, R.; Zhou, J.; Duchesne, P.N.; Zhang, P.; Chen, F.; Han, N.; Zhao, F.; et al. Promoting Effect of $\mathrm{Ni}(\mathrm{OH})_{2}$ on Palladium Nanocrystals Leads to Greatly Improved Operation Durability for Electrocatalytic Ethanol Oxidation in Alkaline Solution. Adv. Mater. 2017, 29, 1703057. [CrossRef] [PubMed]

57. Wang, W.; Zhang, J.; Yang, S.; Ding, B.; Song, X. Au@Pd Core-Shell Nanobricks with Concave Structures and Their Catalysis of Ethanol Oxidation. ChemSusChem 2013, 6, 1945-1951. [CrossRef] [PubMed]

58. Liu, H.; Yang, D.; Bao, Y.; Yu, X.; Feng, L. One-step efficiently coupling ultrafine Pt-Ni ${ }_{2} \mathrm{P}$ nanoparticles as robust catalysts for methanol and ethanol electro-oxidation in fuel cells reaction. J. Power Sources 2019, 434, 226754. [CrossRef]

59. Wang, F.; Fang, B.; Yu, X.; Feng, L. Coupling Ultrafine Pt Nanocrystals over the $\mathrm{Fe}_{2} \mathrm{P}$ Surface as a Robust Catalyst for Alcohol Fuel Electro-Oxidation. ACS Appl. Mater. Interfaces 2019, 11, 9496-9503. [CrossRef]

60. Xu, Z.; Rao, L.; Song, H.; Yan, Z.; Zhang, L.; Yang, S. Enhanced ethanol electro-oxidation on $\mathrm{CeO}_{2}$-modified $\mathrm{Pt} / \mathrm{Ni}$ catalysts in alkaline solution. Chin. J. Catal. 2017, 38, 305-312. [CrossRef]

61. Gruzel, G.; Piekarz, P.; Pawlyta, M.; Donten, M.; Parlinska-Wojtan, M. Preparation of Pt-skin PtRhNi Nanoframes Decorated with Small $\mathrm{SnO}_{2}$ Nanoparticles as an Efficient Catalyst for Ethanol Oxidation Reaction. ACS Appl. Mater. Interfaces 2019, 11, 22352-22363. [CrossRef]

62. Lin, M.-L.; Lo, M.-Y.; Mou, C.-Y. PtRuP nanoparticles supported on mesoporous carbon thin film as highly active anode materials for direct methanol fuel cell. Catal. Today 2011, 160, 109-115. [CrossRef]

63. Wang, F.; Xue, H.; Tian, Z.; Xing, W.; Feng, L. Fe ${ }_{2} \mathrm{P}$ as a novel efficient catalyst promoter in Pd/C system for formic acid electro-oxidation in fuel cells reaction. J. Power Sources 2018, 375, 37-42. [CrossRef]

64. Chang, J.; Feng, L.; Jiang, K.; Xue, H.; Cai, W.-B.; Liu, C.; Xing, W. Pt-CoP/C as an alternative PtRu/C catalyst for direct methanol fuel cells. J. Mater. Chem. A 2016, 4, 18607-18613. [CrossRef]

65. Stern, L.-A.; Feng, L.; Song, F.; Hu, X. Ni ${ }_{2} \mathrm{P}$ as a Janus catalyst for water splitting: The oxygen evolution activity of $\mathrm{Ni}_{2} \mathrm{P}$ nanoparticles. Energy Environ. Sci. 2015, 8, 2347-2351. [CrossRef]

66. Kowal, A.; Li, M.; Shao, M.; Sasaki, K.; Vukmirovic, M.B.; Zhang, J.; Marinkovic, N.S.; Liu, P.; Frenkel, A.I.; Adzic, R.R. Ternary Pt/Rh/SnO 2 electrocatalysts for oxidizing ethanol to $\mathrm{CO}_{2}$. Nat. Mater. 2009, 8, 325-330. [CrossRef]

67. Fan, X.; Tang, M.; Wu, X.; Luo, S.; Chen, W.; Song, X.; Quan, Z. SnO 2 patched ultrathin PtRh nanowires as efficient catalysts for ethanol electrooxidation. J. Mater. Chem. A 2019, 7, 27377-27382. [CrossRef]

68. Huang, J.; Liu, Y.; Xu, M.; Wan, C.; Liu, H.; Li, M.; Huang, Z.; Duan, X.; Pan, X.; Huang, Y. PtCuNi Tetrahedra Catalysts with Tailored Surfaces for Efficient Alcohol Oxidation. Nano Lett. 2019, 19, 5431-5436. [CrossRef]

69. Mao, J.; Chen, W.; He, D.; Wan, J.; Pei, J.; Dong, J.; Wang, Y.; An, P.; Jin, Z.; Xing, W. Design of ultrathin Pt-Mo-Ni nanowire catalysts for ethanol electrooxidation. Sci. Adv. 2017, 3, e1603068. [CrossRef]

70. Shakibi Nia, N.; Guillén-Villafuerte, O.; Griesser, C.; Manning, G.; Kunze-Liebhäuser, J.; Árevalo, C.; Pastor, E.; Garcia, G. $\mathrm{W}_{2} \mathrm{C}$-supported PtAuSn-a catalyst with the earliest ethanol oxidation onset potential and the highest ethanol conversion efficiency to $\mathrm{CO}_{2}$ known to date. ACS Catal. 2020, 10, 1113-1122. [CrossRef]

71. Chen, C.; Kang, Y.; Huo, Z.; Zhu, Z.; Huang, W.; Xin, H.L.; Snyder, J.D.; Li, D.; Herron, J.A.; Mavrikakis, M. Highly crystalline multimetallic nanoframes with three-dimensional electrocatalytic surfaces. Science 2014, 343, 1339-1343. [CrossRef]

72. Yan, Z.; Xu, Z.; Yu, J.; Jaroniec, M. Enhanced formaldehyde oxidation on $\mathrm{CeO}_{2} / \mathrm{AlOOH}$-supported Pt catalyst at room temperature. Appl. Catal. B Environ. 2016, 199, 458-465. [CrossRef] 
73. Paulo, M.J.; Venancio, R.H.D.; Freitas, R.G.; Pereira, E.C.; Tavares, A.C. Investigation of the electrocatalytic activity for ethanol oxidation of Pt nanoparticles modified with small amount ( $\leq 5 \mathrm{wt} \%$ ) of $\mathrm{CeO}_{2}$. J. Electroanal. Chem. 2019, 840, 367-375. [CrossRef]

74. Lee, K.-S.; Park, I.-S.; Cho, Y.-H.; Jung, D.-S.; Jung, N.; Park, H.-Y.; Sung, Y.-E. Electrocatalytic activity and stability of $\mathrm{Pt}$ supported on $\mathrm{Sb}$-doped $\mathrm{SnO}_{2}$ nanoparticles for direct alcohol fuel cells. J. Catal. 2008, 258, 143-152. [CrossRef]

75. Flórez-Montaño, J.; García, G.; Guillén-Villafuerte, O.; Rodríguez, J.L.; Planes, G.A.; Pastor, E. Mechanism of ethanol electrooxidation on mesoporous Pt electrode in acidic medium studied by a novel electrochemical mass spectrometry set-up. Electrochim. Acta 2016, 209, 121-131. [CrossRef]

76. Wang, J.; Cao, X.; Fang, L.; You, X.; Wong, K.; Cao, S.; Xiao, C.; Cai, S.; Huang, Y.; Zhang, X. MoS 2 nanoflower supported Pt nanoparticle as an efficient electrocatalyst for ethanol oxidation reaction. Int. J. Hydrogen Energy 2019, 44, 16411-16423. [CrossRef]

77. Eshghi, A.; Sadati Behbahani, E.; Kheirmand, M.; Ghaedi, M. Pd, Pd-Ni and Pd-Ni-Fe nanoparticles anchored on $\mathrm{MnO}_{2} /$ Vulcan as efficient ethanol electro-oxidation anode catalysts. Int. J. Hydrogen Energy 2019, 44, 28194-28205. [CrossRef]

78. Bhattacharya, A.; Hazra, A.; Chatterjee, S.; Sen, P.; Laha, S.; Basumallick, I. Expanded graphite as an electrode material for an alcohol fuel cell. J. Power Sources 2004, 136, 208-210. [CrossRef]

79. Rajesh, D.; Neel, P.I.; Pandurangan, A.; Mahendiran, C. Pd-NiO decorated multiwalled carbon nanotubes supported on reduced graphene oxide as an efficient electrocatalyst for ethanol oxidation in alkaline medium. Appl. Surf. Sci. 2018, 442, 787-796. [CrossRef]

80. Zhuang, Z.; Chen, W. Ultra-low loading of $\mathrm{Pd}_{5}$ nanoclusters on carbon nanotubes as bifunctional electrocatalysts for the oxygen reduction reaction and the ethanol oxidation reaction. J. Colloid Interface Sci. 2019, 538, 699-708. [CrossRef]

81. Cazetta, A.L.; Zhang, T.; Silva, T.L.; Almeida, V.C.; Asefa, T. Bone char-derived metal-free N- and S-co-doped nanoporous carbon and its efficient electrocatalytic activity for hydrazine oxidation. Appl. Catal. B Environ. 2018, 225, 30-39. [CrossRef]

82. Wan, W.; Wang, Q.; Zhang, L.; Liang, H.-W.; Chen, P.; Yu, S.-H. N-, P- and Fe-tridoped nanoporous carbon derived from plant biomass: An excellent oxygen reduction electrocatalyst for zinc-air batteries. J. Mater. Chem. A 2016, 4, 8602-8609. [CrossRef]

83. Yu, K.; Lin, Y.; Fan, J.; Li, Q.; Shi, P.; Xu, Q.; Min, Y. Ternary N, S, and P-Doped Hollow Carbon Spheres Derived from Polyphosphazene as Pd Supports for Ethanol Oxidation Reaction. Catalysts 2019, 9, 114. [CrossRef]

84. Li, Z.; Zhang, L.; Yang, C.; Chen, J.; Wang, Z.; Bao, L.; Wu, F.; Shen, P. Graphitized carbon nanocages/palladium nanoparticles: Sustainable preparation and electrocatalytic performances towards ethanol oxidation reaction. Int. J. Hydrogen Energy 2019, 44, 6172-6181. [CrossRef]

85. Lv, H.; Mu, S. Nano-ceramic support materials for low temperature fuel cell catalysts. Nanoscale 2014, 6, 5063-5074. [CrossRef]

86. Al-Youbi, A.O.; Gómez de la Fuente, J.L.; Pérez-Alonso, F.J.; Obaid, A.Y.; Fierro, J.L.G.; Peña, M.A.; Abdel Salam, M.; Rojas, S. Effects of multiwalled carbon nanotube morphology on the synthesis and electrocatalytic performance of Pt supported by multiwalled carbon nanotubes. Appl. Catal. B Environ. 2014, 150-151, 21-29. [CrossRef]

87. Deng, H.; Li, Q.; Liu, J.; Wang, F. Active sites for oxygen reduction reaction on nitrogen-doped carbon nanotubes derived from polyaniline. Carbon 2017, 112, 219-229. [CrossRef]

88. Yang, H.; Zhang, X.; Zou, H.; Yu, Z.; Li, S.; Sun, J.; Chen, S.; Jin, J.; Ma, J. Palladium nanoparticles anchored on three-dimensional nitrogen-doped carbon nanotubes as a robust electrocatalyst for ethanol oxidation. ACS Sustain. Chem. Eng. 2018, 6, 7918-7923. [CrossRef]

89. Ning, L.; Liu, X.; Deng, M.; Huang, Z.; Zhu, A.; Zhang, Q.; Liu, Q. Palladium-based nanocatalysts anchored on CNT with high activity and durability for ethanol electro-oxidation. Electrochim. Acta 2019, 297, $206-214$. [CrossRef]

90. Stankovich, S.; Dikin, D.A.; Dommett, G.H.; Kohlhaas, K.M.; Zimney, E.J.; Stach, E.A.; Piner, R.D.; Nguyen, S.T.; Ruoff, R.S. Graphene-based composite materials. Nature 2006, 442, 282. [CrossRef] 
91. Dong, L.; Gari, R.R.S.; Li, Z.; Craig, M.M.; Hou, S. Graphene-supported platinum and platinum-ruthenium nanoparticles with high electrocatalytic activity for methanol and ethanol oxidation. Carbon 2010, 48, 781-787. [CrossRef]

92. Tan, J.L.; De Jesus, A.M.; Chua, S.L.; Sanetuntikul, J.; Shanmugam, S.; Tongol, B.J.V.; Kim, H. Preparation and characterization of palladium-nickel on graphene oxide support as anode catalyst for alkaline direct ethanol fuel cell. Appl. Catal. A Gen. 2017, 531, 29-35. [CrossRef]

93. Liu, Q.; Jiang, K.; Fan, J.; Lin, Y.; Min, Y.; Xu, Q.; Cai, W.-B. Manganese Dioxide Coated Graphene Nanoribbons Supported Palladium Nanoparticles as an Efficient Catalyst for Ethanol Electrooxidation in Alkaline Media. Electrochim. Acta 2016, 203, 91-98. [CrossRef]

94. Alfi, N.; Yazdan-Abad, M.Z.; Rezvani, A.; Noroozifar, M.; Khorasani-Motlagh, M. Three-dimensional Pd-Cd nanonetwork decorated on reduced graphene oxide by a galvanic method as a novel electrocatalyst for ethanol oxidation in alkaline media. J. Power Sources 2018, 396, 742-748. [CrossRef]

95. Jia, X.; Guan, Q.; Chen, Y.; Wang, Y.; Zhao, Q.; Li, J. Poly (triazine imide) (PTI) and graphene hybrids supported PtSn catalysts for enhanced electrocatalytic oxidation of ethanol. Appl. Surf. Sci. 2019, 492, 879-885. [CrossRef]

96. Sun, S.; Halseid, M.C.; Heinen, M.; Jusys, Z.; Behm, R.J. Ethanol electrooxidation on a carbon-supported Pt catalyst at elevated temperature and pressure: A high-temperature/high-pressure DEMS study. J. Power Sources 2009, 190, 2-13. [CrossRef]

97. Engl, T.; Gubler, L.; Schmidt, T.J. Fuel electrode carbon corrosion in high temperature polymer electrolyte fuel cells-crucial or irrelevant? Energy Technol. 2016, 4, 65-74. [CrossRef]

98. Han, S.H.; Liu, H.M.; Chen, P.; Jiang, J.X.; Chen, Y. Porous trimetallic PtRhCu cubic nanoboxes for ethanol electrooxidation. Adv. Energy Mater. 2018, 8, 1801326. [CrossRef]

99. Ferreira, H.S.; Ferreira, H.S.; Gliech, M.; Bergmann, A.; Beermann, V.; Rangel, M.d.C.; Eguiluz, K.I.B.; Salazar-Banda, G.R. Synthesis of $\mathrm{Ni}_{-} \mathrm{SiO}_{2} / \mathrm{C}$ Supported Platinum Catalysts for Improved Electrochemical Activity Towards Ethanol Oxidation. J. Nanosci. Nanotechnol. 2019, 19, 4590-4598. [CrossRef]

100. Tackett, B.M.; Sheng, W.; Chen, J.G. Opportunities and Challenges in Utilizing Metal-Modified Transition Metal Carbides as Low-Cost Electrocatalysts. Joule 2017, 1, 253-263. [CrossRef]

101. García, G.; Guillén-Villafuerte, O.; Rodríguez, J.L.; Arévalo, M.C.; Pastor, E. Electrocatalysis on metal carbide materials. Int. J. Hydrogen Energy 2016, 41, 19664-19673. [CrossRef]

102. Zhao, F.-M.; Wu, S.-Z.; Chen, Z.-Y.; Chu, Y.-Q.; Shi, M.-Q. Alkali-induced self-assembly Pd/Ni-Mo $2 \mathrm{C}$ nanocatalyst for ethanol electro-oxidation. J. Fuel Chem. Technol. 2019, 47, 574-581. [CrossRef]

103. Li, Z.; Chen, Y.; Fu, G.; Chen, Y.; Sun, D.; Lee, J.-M.; Tang, Y. Porous PdRh nanobowls: Facile synthesis and activity for alkaline ethanol oxidation. Nanoscale 2019, 11, 2974-2980. [CrossRef] [PubMed]

104. Zhao, Y.; He, X.; Chen, R.; Liu, Q.; Liu, J.; Yu, J.; Li, J.; Zhang, H.; Dong, H.; Zhang, M. A flexible all-solid-state asymmetric supercapacitors based on hierarchical carbon cloth@CoMoO${ }_{4} @ \mathrm{NiCo}$ layered double hydroxide core-shell heterostructures. Chem. Eng. J. 2018, 352, 29-38. [CrossRef]

105. Pi, M.; Wang, X.; Zhang, D.; Wang, S.; Chen, S. A 3D porous $\mathrm{WP}_{2}$ nanosheets@carbon cloth flexible electrode for efficient electrocatalytic hydrogen evolution. Front. Chem. Sci. Eng. 2018, 12, 425-432. [CrossRef]

106. Wang, A.-L.; He, X.-J.; Lu, X.-F.; Xu, H.; Tong, Y.-X.; Li, G.-R. Palladium-Cobalt Nanotube Arrays Supported on Carbon Fiber Cloth as High-Performance Flexible Electrocatalysts for Ethanol Oxidation. Angew. Chem. Int. Ed. 2015, 54, 3669-3673. [CrossRef]

107. Chen, G.-F.; Luo, Y.; Ding, L.-X.; Wang, H. Low-Voltage Electrolytic Hydrogen Production Derived from Efficient Water and Ethanol Oxidation on Fluorine-Modified FeOOH Anode. ACS Catal. 2018, 8, 526-530. [CrossRef]

108. Barakat, N.A.; Abdelkareem, M.A.; Kim, H.Y. Ethanol electro-oxidation using cadmium-doped cobalt/carbon nanoparticles as novel non precious electrocatalyst. Appl. Catal. A Gen. 2013, 455, 193-198. [CrossRef]

109. Barakat, N.A.; Motlak, M.; Elzatahry, A.A.; Khalil, K.A.; Abdelghani, E.A. $\mathrm{Ni}_{\mathrm{x}} \mathrm{Co}_{1-\mathrm{x}}$ alloy nanoparticle-doped carbon nanofibers as effective non-precious catalyst for ethanol oxidation. Int. J. Hydrogen Energy 2014, 39, 305-316. [CrossRef]

110. Hatamie, A.; Rezvani, E.; Rasouli, A.S.; Simchi, A. Electrocatalytic Oxidation of Ethanol on Flexible Three-dimensional Interconnected Nickel/Gold Composite Foams in Alkaline Media. Electroanalysis 2019, 31, 504-511. [CrossRef] 
111. Soliman, A.B.; Abdel-Samad, H.S.; Rehim, S.S.A.; Ahmed, M.A.; Hassan, H.H. High performance nano-Ni/graphite electrode for electro-oxidation in direct alkaline ethanol fuel cells. J. Power Sources 2016, 325, 653-663. [CrossRef]

112. Zolfaghari, M.; Arab, A.; Asghari, A. Surfactant-Assisted Electrodeposition of Nickel Nanostructures and Their Electrocatalytic Activities Toward Oxidation of Sodium Borohydride, Ethanol, and Methanol. Chem. Sel. 2019, 4, 4487-4495. [CrossRef]

113. Vyas, A.N.; Desai, M.A.; Phase, D.M.; Saratale, R.G.; Ambekar, J.D.; Kale, B.B.; Pathan, H.M.; Sartale, S.D. Nickel nanoparticles grown by successive ionic layer adsorption and reaction method for ethanol electrooxidation and electrochemical quartz crystal microbalance study. New J. Chem. 2019, 43, 2955-2965. [CrossRef]

114. Tammam, R.H.; Touny, A.; Abdesalam, M.E.; Saleh, M. Mesoporous NiPh/carbon fibers nanocomposite for enhanced electrocatalytic oxidation of ethanol. J. Electroanal. Chem. 2018, 823, 128-136. [CrossRef]

115. Sharma, P.; Radhakrishnan, S.; Khil, M.-S.; Kim, H.-Y.; Kim, B.-S. Simple room temperature synthesis of porous nickel phosphate foams for electrocatalytic ethanol oxidation. J. Electroanal. Chem. 2018, 808, 236-244. [CrossRef]

116. Nakamura, A.; Takahashi, H.; Takeguchi, T.; Yamanaka, T.; Wang, Q.; Uchimoto, Y.; Ueda, W.J.E.T. Performance of Fe-Co-Ni/C Anode Catalyst on Direct Ethanol Fuel Cell. ECS Trans. 2011, 41, 2205-2209.

117. Mohamed, I.M.A.; Motlak, M.; Obaid, M.; Alsoufi, M.S.; Bawazeer, T.M.; Mohamed, A.F.; Barakat, N.A.M. $\mathrm{Co} / \mathrm{Cr}$-Decorated Carbon Nanofibers as Novel and Efficacious Electrocatalyst for Ethanol Oxidation in Alkaline Medium. J. Nanosci. Nanotechnol. 2017, 17, 1280-1286. [CrossRef]

118. Chaitree, W.; Kalu, E.E. Co-Ni-Mo as a Non-Noble Metal Electrocatalyst for Ethanol Electro-Oxidation. J. Electrochem. Soc. 2019, 166, H392-H403. [CrossRef]

119. Tolba, G.M.K.; Barakat, N.A.M.; Bastaweesy, A.M.; Ashour, E.A.; Abdelmoez, W.; El-Newehy, M.H.; Al-Deyab, S.S.; Kim, H.Y. Hierarchical $\mathrm{TiO}_{2} / \mathrm{ZnO}$ Nanostructure as Novel Non-precious Electrocatalyst for Ethanol Electrooxidation. J. Mater. Sci. Technol. 2015, 31, 97-105. [CrossRef]

120. Zhan, J.; Cai, M.; Zhang, C.; Wang, C. Synthesis of mesoporous $\mathrm{NiCo}_{2} \mathrm{O}_{4}$ fibers and their electrocatalytic activity on direct oxidation of ethanol in alkaline media. Electrochim. Acta 2015, 154, 70-76. [CrossRef]

121. Jayaseelan, S.S.; Ko, T.-H.; Radhakrishnan, S.; Yang, C.-M.; Kim, H.-Y.; Kim, B.-S. Novel MWCNT interconnected $\mathrm{NiCO}_{2} \mathrm{O}_{4}$ aerogels prepared by a supercritical $\mathrm{CO}_{2}$ drying method for ethanol electrooxidation in alkaline media. Int. J. Hydrogen Energy 2016, 41, 13504-13512. [CrossRef] 